\title{
Considerações sobre o perfil do alforriado em Rio de Contas, Bahia (século XIX)
}

\author{
Kátia Lorena Novais Almeida
}

O povoamento da região de Rio de Contas deu-se com a criação de gado que adentrou o sertão, margeando o curso do rio São Francisco e seus afluentes. ${ }^{1} \mathrm{O}$ seu desenvolvimento econômico expandiu-se a partir das descobertas auríferas, as quais, na segunda década do século XVIII, transformaram o Alto Sertão da Bahia, atraindo pessoas de muitas partes da colônia e da metrópole, seduzidas pela promessa do ouro abundante. ${ }^{2}$ A produção aurífera, considerável nos primeiros tempos da mineração, declinou ainda no Setecentos, ao tempo em que se expandia a pecuária e a agricultura, voltadas para os mercados local e regional. ${ }^{3}$

A vila de Rio de Contas era o núcleo urbano mais importante do município e constituía um centro de comércio e administração, cuja renda originava-se da agricultura e da pecuária. No entorno desse núcleo existia uma extensa zona rural - com fazendas, sítios e roças -, onde se plantava mandioca, milho, feijão e arroz. Produzia-se ainda o algodão, que era levado pelos tropeiros até o porto de São Felix, e daí para Salvador, e a cana-de-açúcar cultivada em pequena escala, mas o suficiente para o consumo local dos seus derivados, como a rapadura e a aguardente. A pecuária foi outra atividade importante para a região, sendo o gado vacum vendido para outros centros consumidores, fornecendo carne seca para o mercado vicinal e o couro que servia a diversos fins. ${ }^{4}$

Este artigo discute o perfil do alforriado no município de Rio de Contas ao longo do século XIX. Inicialmente, analisamos a população escrava no período entre 1800 a 1850 , porque nos interessa perceber qual era a sua composição, nessa região, no período de vigência do tráfico transatlântico de escravos. Em um segundo momento, examinamos o perfil do alforriado entre 1800 a 1888, comparando-o ao da população escrava, o que possibilita mensurar quem era o escravo com mais chances de se libertar na região. Dividimos essa análise em três períodos marcados por mudanças relevantes na história da escravidão e da liberdade no século XIX, as leis Eusébio de Queiroz (1850), a do Ventre Livre, (1871) e Áurea (1888). A base empírica do artigo é uma amostra de inventários post-mortem e as cartas de alforria registradas nos Livros de Notas do Tabelião de Rio de Contas.

A singularidade desse estudo reside no fato de essa ser uma regiāo caracterizada por atividades essencialmente rurais, além do que restou dos tempos áureos da mineração, portanto, uma região que representa um contraponto a outras da Bahia onde esse mesmo tema, a alforria, tem sido abordado.

\section{Composição da população cativa em Rio de Contas}

As estimativas sobre a população no Brasil anteriores ao censo de 1872 são raras e precárias. Os dados disponíveis são provenientes de censos eclesiásticos e militares de âmbito regional, além de avaliações mais amplas da população, feitas, entre outros, por viajantes estrangeiros. Infelizmente, não dispomos de listas nominativas de habitantes ou mapas da população que indiquem a composição da população do município de Rio de Contas na primeira metade do século XIX. Em 1818, os naturalistas Johann Spix e Karl F. von Martius estimaram que a vila possuía 900 moradores e o município 9.000 habitantes. ${ }^{5}$ Contudo, este tipo de estimativa não dá conta de informar a proporção da população livre e escrava, e muito menos as características desta última, que é o que mais nos interessa aqui. A falta de censo populacional para essa região levou-nos a buscar as informações sobre a composição interna da população escrava em uma amostra de inventários post-mortem, que resultaram nos dados da Tabela 1. A amostra fornece informaçōes sobre o sexo e a naturalidade de 1.477 cativos pertencentes a 161 proprietários. $^{6}$ 
Tabela 1 - Origem, nação, cor e sexo da população cativa em Rio de Contas (1800-1850)

\begin{tabular}{|l|c|c|c|c|c|c|c|}
\hline \multicolumn{1}{|c|}{ Origem } & Homem & $\%$ & Mulher & $\%$ & Total & \% do Grupo & \% do Total \\
\hline África Ocidental & & & & & & & \\
\hline Mina & 48 & 5,6 & 30 & 4,8 & 78 & 22,6 & 5,3 \\
\hline Calabar & 19 & 2,2 & 18 & 2,9 & 37 & 10,7 & 2,5 \\
\hline Haussá & 25 & 2,9 & 8 & 1,3 & 33 & 9,6 & 2,2 \\
\hline Nagô & 19 & 2,2 & 4 & 0,6 & 23 & 6,6 & 1,6 \\
\hline Tapa & 2 & 0,2 & & & 2 & 0,6 & 0,1 \\
\hline Benin & 1 & 0,1 & 1 & 0,2 & 2 & 0,6 & 0,1 \\
\hline Jeje & & & 1 & 0,2 & 1 & 0,3 & 0,1 \\
\hline África Centro-Ocidental & & & & & & & \\
\hline Angola & 64 & 7,5 & 22 & 3,5 & 86 & 24,9 & 5,8 \\
\hline Congo & 11 & 1,3 & & & 11 & 3,2 & 0,7 \\
\hline Cabinda & 6 & 0,7 & 1 & 0,2 & 7 & 2,0 & 0,5 \\
\hline Benguela & 5 & 0,6 & & & 5 & 1,4 & 0,3 \\
\hline Monjolo & 3 & 0,4 & & & 3 & 0,9 & 0,2 \\
\hline Cassange & 1 & 0,1 & & & 1 & 0,3 & 0,1 \\
\hline África Oriental & & & & & & & \\
\hline Moçambique & 2 & 0,2 & & & 2 & 0,6 & 0,1 \\
\hline Não identificado & 36 & 4,2 & 18 & 2,9 & 54 & 15,7 & 3,7 \\
\hline Total nascidos na África & 242 & 28,2 & 103 & 16,6 & 345 & 100 & 23,3 \\
\hline Brasil & & & & & & & 40,6 \\
\hline Crioulos & 340 & 39,7 & 259 & 41,8 & 599 & 57,8 & 40,6 \\
\hline Cabras & 134 & 15,6 & 103 & 16,6 & 237 & 22,9 & 16,1 \\
\hline Pardos & 44 & 4,7 & 56 & 9,0 & 100 & 9,7 & 6,8 \\
\hline Mulatos & 36 & 4,2 & 52 & 8,4 & 88 & 8,5 & 6,0 \\
\hline Mestiço & 5 & 0,6 & 6 & 1,0 & 11 & 1,1 & 0,7 \\
\hline Total nascidos no Brasil & 559 & 65,2 & 476 & 76,8 & 1035 & 100 & 70,1 \\
\hline Sem informação & 56 & 6,6 & 41 & 6,6 & 97 & & 6,6 \\
\hline Total geral & 857 & 100 & 620 & 100 & 1477 & & 100 \\
\hline
\end{tabular}

Fonte: AMRC, Seção Judiciário, Inventários post-mortem. Foram selecionados para estudo três anos de cada uma das décadas compreendidas no período de 1800 a 1850.

Vejamos, inicialmente, a distribuição da população cativa em Rio de Contas segundo sua origem e sexo, entre os anos de 1800 a 1850 , período em que o tráfico transatlântico encontrava-se aberto no Brasil. Interessa-nos, sobretudo, perceber a influência deste comércio na composição da população cativa do município de Rio de Contas neste período e, por esta razão, a análise restringe-se à primeira metade do Oitocentos.

O padrão demográfico que emerge desses inventários indica que os escravos nascidos no Brasil representavam $70 \%$ do total da população cativa na primeira metade do século XIX, ocorrendo uma oscilação somente na década de 1820, quando o número de cativos nascidos na África elevou-se para $46,7 \%$. Esse cenário contrasta com o que a historiografia indica para Salvador e para o Recôncavo açucareiro no mesmo período, onde foi elevado o número de escravos desembarcados da África. ${ }^{7}$

A proporção de escravos nascidos na África, em um contexto de tráfico atlântico aberto, é um indicador da participação de uma região, cidade ou vila no comércio de escravos. Isto significa que, se um proprietário de escravos dependesse essencialmente do tráfico transatlântico para repor sua escravaria, esta se caracterizaria por um maior número de escravos de origem africana. Este não foi o caso de Rio de Contas. O fato de a proporção de escravos de origem africana no município, no período de 1800-1850, ser de 23,3\% denotava pouca participação dessa região nesse comércio. Entretanto, não podemos afirmar que os nascidos no Brasil sempre constituíram a maioria da população cativa nessa região, porque, 
em meados do século XVIII, no auge da produção aurífera, os escravos de origem africana representavam 90,2\% daqueles listados no Livro de Matrícula de escravos entre 1748 a $1749 .{ }^{8}$ A crise do ouro de aluvião e a diversificação econômica pela qual passou a região parecem ter redefinido o seu cenário étnico. A agricultura, principalmente a de abastecimento interno, e a pecuária passaram a ser as principais atividades, e os rendimentos daí proveniente não eram tão altos como aqueles da produção aurífera, o que impedia os senhores de renovarem suas escravarias com cativos oriundos da África.

No Brasil, o tráfico transatlântico importou mais homens do que mulheres. Por isso, quanto mais uma região importasse cativos, maior razão ou taxa de masculinidade teria sua população escrava. ${ }^{9}$ A razão de masculinidade de 426 homens para 100 mulheres é bastante alta dentre os escravos naquela Lista de Matrícula. ${ }^{10}$ Quando, nessa mesma região, a mineração declinou e ela deixou de absorver maciçamente cativos importados, a razão de masculinidade na população cativa diminuiu de maneira significativa.

Os escravistas de Rio de Contas ainda adquiriam escravos de origem africana, mas em um número significativamente menor do que no século XVIII. Quanto maior a presença de cativos nascidos no Brasil, mais equilibrada era a razão de masculinidade. Desse modo, na primeira metade do século XIX a população escrava exibia uma taxa de masculinidade de 138 homens para 100 mulheres (Tabela 1). Essa taxa era mais elevada entre os cativos de origem africana, 235 para 100, do que entre os escravos nascidos no Brasil, que era de 117 . Essa disparidade confirma que a quantidade de africanos na população cativa era responsável pelo desequilíbrio entre os sexos.

Ao compararmos a taxa de masculinidade em Rio de Contas com a detectada para o Recôncavo baiano, verificamos que ela foi mais ou menos elevada dependendo do tipo de lavoura. Bert Barickman encontrou nas lavouras de mandioca dessa região uma relação de 108 homens para 100 mulheres e, nas lavouras de fumo, de 106 homens para 100 mulheres, em ambos os casos taxas mais baixas do que na região em estudo. Entretanto, a taxa detectada para Rio de Contas é significativamente menor do que a dos engenhos e fazendas de cana-de-açúcar na região do Iguape, também no Recôncavo, que era de 152 homens para 100 mulheres. ${ }^{11}$ Para Barickman, os preços dos cativos do sexo masculino e feminino poderiam explicar os índices mais equilibrados na razão de masculinidade entre os escravos dos lavradores de mandioca. Os preços mais elevados, em torno de $20 \%$, dos escravos do sexo masculino direcionaram a preferência desses lavradores para a aquisição de escravas, equilibrando, portanto, a razão de masculinidade. Em Rio de Contas, o preço dos escravos do sexo masculino, entre 13 e 45 anos, um pouco mais elevado que o das escravas nas mesmas condiçôes, parece ter, a exemplo dos lavradores de mandioca, direcionado a aquisição para as cativas do sexo feminino, aumentando deste modo o seu número na população cativa e influenciado o processo de crioulização. ${ }^{12}$

As pesquisas têm demonstrado que Salvador foi um núcleo de alta concentração de africanos. ${ }^{13} \mathrm{O}$ mesmo não se verifica nos núcleos urbanos do Alto Sertão. Em Rio de Contas, durante o século XIX, a maioria da população cativa estava nas áreas rurais. ${ }^{14}$ Os cativos que residiam na vila, arraiais, fazendas e sítios, em Rio de Contas, nas três primeiras décadas do Oitocentos, eram predominantemente nascidos no Brasil, sem grandes variações nas duas primeiras décadas. Houve apenas uma oscilação na década de 1830 , com uma vantagem de $17,3 \%$ a favor dos africanos que residiam na vila e povoações. Isto significa que a crioulização demográfica, isto é, "o crescimento da população crioula (crioulo aqui entendido como indivíduo negro de ascendência africana nascido no Brasil)", como a definiu Nicolau Parés, atingiu tanto o espaço urbano quanto o rural do município em estudo, tendo se iniciado esse processo antes da extinção do tráfico atlântico em 1850 , como consequência da sua própria dinâmica econômica. ${ }^{15}$

Um outro aspecto a ser considerado no aumento da população cativa nascida no Brasil é a formação de famílias escravas. ${ }^{16} \mathrm{~A}$ amostra de inventários post-mortem de Rio de Contas, referente à primeira metade do século XIX, registra 9,2\% de escravos casados, na faixa etária de 15 a 60 anos. Um mapa dos casamentos realizados na freguesia de Bom Jesus de Rio de Contas, entre os anos de 1843 e 1847, informa que 26 escravos se casaram com escravas e 23 pessoas livres se casaram com escravos. $O$ total de casamentos realizados naquela freguesia no mesmo período foi de 954, e os casamentos envolvendo es- 
cravos representaram apenas 5,1\%. No ano de 1848, foram realizados 110 casamentos e, destes, 2,7\% foram entre escravos e $1,8 \%$ entre livres e escravos. ${ }^{17}$

Os dados referentes à freguesia do Santíssimo Sacramento de Minas do Rio de Contas indicam que, no ano de 1846, realizaram-se 155 casamentos, sendo 5,8\% deles entre escravos e $2 \%$ entre escravos com livres. No ano de 1848, foram realizados 115 casamentos, sendo 9,6\% deles entre escravos. Estes são percentuais muito baixos de uniōes legitimadas pela Igreja, mas as possibilidades de organização familiar iam além do casamento formal. Ademais, o padre Jerônimo de Souza Barbosa ressaltou que os dados sobre os assentos de óbito e batismos eram "assaz imperfeitos" porque as filiais dessa freguesia não os remetiam, e inferimos que o mesmo poderia ocorrer com os registros de casamentos. ${ }^{18}$ Também não podemos esquecer que havia escravas que engravidavam de senhores que mantinham esses filhos cativos.

Outro método para avaliar o processo de crioulização demográfica é por meio da taxa geral de fecundidade ou razão criança/mulher, que indica a capacidade ou não de reprodução da população. Em Rio de Contas, os inventários listam um total de 235 crianças nascidas no Brasil com até cinco anos, ou uma proporção de 84 crianças para 100 escravas entre 14 e 44 anos. A proporção encontrada para as fazendas e sítios de fumo do Recôncavo baiano foi de 85 crianças para 100 cativas. ${ }^{19}$ Essas proporções são consideradas baixas, mas permitem um crescimento sustentado dessa população se combinado com outros índices. Assim, a taxa de fecundidade também fornece uma estimativa do número de filhos sobreviventes que as cativas tinham durante suas vidas. A taxa de sobrevivências dos filhos das escravas em Rio de Contas foi de 5\%. Barickman detectou, para a região fumageira, uma taxa um pouco superior a 2,5\%, enquanto no Iguape, ela foi, em média, apenas de 1,89\%. De acordo com esse autor, "para que uma população seja capaz de se reproduzir naturalmente, uma média de dois é suficiente". ${ }^{20} \mathrm{O}$ que estes cálculos nos dizem é que a população cativa de Rio de Contas tinha uma taxa de sobrevivência que possibilitava a reprodução natural da mão de obra escrava, o que se confirma pelo índice de escravos nascidos no Brasil. ${ }^{21}$

Para Barickman, aquelas estimativas de taxa de sobrevivência são "reconhecidamente grosseiras" por não levarem plenamente em conta a mortalidade infantil e adulta, e por superestimarem o número médio de crianças sobreviventes. No entanto, indicam diferenças significativas "nas taxas de fecundidade entre as escravas dos engenhos e fazendas de cana do Recôncavo e as que eram empregadas no cultivo de fumo na mesma região". ${ }^{22} \mathrm{O}$ cotejo das taxas de sobrevivência dos filhos das escravas entre essas duas regiōes permite-nos entender por que o número de escravos não caiu rapidamente no município de Rio de Contas, apesar da pouca participação no tráfico transatlântico e da resistência das escravas a ter filhos, por meio de práticas abortivas e dos infanticídios. ${ }^{23}$

O tipo e a quantidade de mão-de-obra empregada na lavoura, bem como a alimentação fornecida à população cativa, influenciaram também na composição da escravaria. Barickman e Nicolau Parés salientaram que o fato de os lavradores de fumo não disporem de recursos financeiros, como os fazendeiros de cana ou os donos de engenho, aliado às especificidades do cultivo do tabaco - que requeria menos esforço físico - resultou na predominância de mulheres, crianças e idosos entre os cativos. Por outro lado, esses autores salientam também a importância de uma dieta alimentar mais rica - decorrente da criação de gado e do cultivo de feijão, milho e farinha nas roças de fumo -, aumentando as taxas de fecundidade da escravaria, o que gerava um crescimento natural. ${ }^{24} \mathrm{~A}$ dieta alimentar dos escravos em Rio de Contas, possivelmente, foi semelhante a dos escravos do Brejo do Campo Seco, composta por carne-seca, farinha de mandioca, e, eventualmente, o feijão e o milho, quiçá colhidos em roças por eles cultivadas. ${ }^{25}$ Dessa forma, as consideraçôes feitas por esses autores a respeito da lavoura fumageira servem para pensar as bases do crescimento da população cativa nascida no Brasil no município de Rio de Contas.

Assim, o fato de, na primeira metade do século XIX, a proporção de cativos nascidos no Brasil ter-se mantido em mais de $50 \%$ sugere que os senhores sertanejos conseguiram manter a população cativa por meio da reprodução natural, uma vez que adquirir cativos de origem africana tinha se tornado proibitivo. Em suma, os senhores sertanejos, à semelhança dos lavradores de fumo e de mandioca do Recônca- 
vo baiano, não dependiam essencialmente do tráfico africano para garantir a força de trabalho em suas atividades produtivas, já na primeira metade do Oitocentos.

Vejamos agora os dados da população cativa em Rio de Contas segundo a nação africana, também registrados na Tabela 1. De acordo com Lorand Matory, o termo nação, usado para designar a origem africana do cativo, há muitos séculos se refere a "um grupo de pessoas unido pela ascendência, língua ou história compartilhada, a ponto de formarem um povo distinto" ${ }^{26}$ Mas o sentido atribuído pelos próprios africanos a uma identidade coletiva era complexo e baseado em diversos critérios como o religioso, político, territorial, linguístico e, sobretudo, o reconhecimento de ancestrais comuns. Transformações como guerras, apropriação de cultos de povos vizinhos, migraçóes ou mudanças políticas, redimensionavam o sentido de pertença ao grupo, de modo dinâmico e plural, mas isto nem sempre implicava uma ruptura radical com fronteiras identitárias anteriores. ${ }^{27}$ Assim, os nomes de nação conhecidos em Rio de Contas, como em outras regiōes, estão, alguns mais, outros menos, próximos das origens específicas dos cativos nascidos na África.

Identificamos 14 termos de nação para 291 escravos de origem africana em Rio de Contas (Tabela 1). Esses termos não se referiam a regiōes específicas ou reinos de origem, mas, em geral, a portos da costa africana que abasteciam o tráfico. ${ }^{28}$ Entretanto, as denominações étnicas e identidades coletivas existentes na África coincidiam com as atribuídas no circuito do tráfico e, aos poucos, foram assumindo, no Brasil, novos sentidos e significados, segundo a época e a região do país. ${ }^{29}$ As nações africanas, mesmo não sendo formas de autodenominações étnicas de uso comum na África, acabaram incorporadas pelos africanos no processo de organização de suas identidades no Novo Mundo, enquanto as denominaçôes étnicas de uso corrente em suas regiōes de origem eram utilizadas em contextos mais reservados da comunidade africana ou afro-brasileira. ${ }^{30}$

$\mathrm{Na}$ amostra analisada, os africanos ocidentais representavam $11,9 \%$, e os africanos centro-ocidentais, $7,6 \%$ do conjunto da população cativa como um todo. Isolando os cativos de origem africana, a participação dos ocidentais foi de $51 \%$, a dos centro-ocidentais, de $32,7 \%$, a dos orientais, de $0,6 \%$ e, para $15,7 \%$, não houve identificação. Vale ressaltar que, nos inventários analisados para a década de 1840 , as informações sobre os termos de nação se tornaram mais raras, aspecto que comentaremos mais adiante.

Dentre os africanos ocidentais, a nação mina foi a mais expressiva com 22,6\%. Enquanto no Rio de Janeiro o termo mina manteve um significado mais amplo, na Bahia ele passou por diversas variações. De acordo com Inês Oliveira, no século XVIII o termo designava os africanos que embarcavam nos portos "controlados pelos reinos de Ardra e Whydá, posteriormente ocupados pelo Daomé", especialmente os das nações jeje (daomeanos) e os nagôs (iorubás). ${ }^{31}$ Em suas pesquisas sobre rebeliōes escravas na Bahia, na primeira metade do século XIX, João Reis, inspirado em Nina Rodrigues, concluiu que mina, além de incluir cativos oriundos dos portos no golfo do Benin, inclusive nagôs, era também um etnônimo específico reconhecido pela comunidade africana dos escravos embarcados do reino de Aneho (Pequeno Popo). ${ }^{32}$ Enfim, mina podia representar uma nação específica, mas a maioria dos escravos assim chamados se abrigavam sob um termo "guarda-chuva" junto com outras nações. ${ }^{33}$

A nação calabar representava $10,7 \%$ do total da população cativa de origem africana. Cabe observar que os cativos provenientes do Calabar, designativo de um porto de embarque na foz do Níger, possivelmente estão superdimensionados porque, na amostra analisada, esses cativos pertenciam todos a um único proprietário, que talvez os tenha adquirido em uma oportunidade de negócios específica. Em Salvador, os escravos desta nação representavam não mais que $2,4 \%$ do total de cativos da África Ocidental no período de $1811-1860 .^{34}$

O percentual de haussás na amostra analisada foi de 9,6\%. Este grupo étnico chegou à Bahia em grande número nas duas primeiras décadas do século XIX. Já o percentual dos nagôs (falantes de língua ioruba) foi de 6,6\% nos inventários post-mortem. Esta nação tornou-se a mais representativa em Salvador nas décadas de 1820 e 1830 . No período de 1811-1830 os nagôs representavam 32,2\% da po- 
pulação cativa procedente da África Ocidental, e entre 1831-1860 esse percentual chegou a $68 \% .{ }^{35}$ Os baixos percentuais destas nações em Rio de Contas confirmam a nossa afirmação anterior de que os senhores sertanejos não mais participavam ativamente do tráfico transatlântico de cativos. Porém, muitos nagôs trazidos no início do século estariam sendo identificados como minas.

Entre os africanos centro-ocidentais, a nação angola foi a mais representativa, com $24,9 \%$, seguida pelas nações congo $(3,2 \%)$, cabinda $(2 \%)$ e benguela $(1,4 \%)$. A nação angola foi uma denominação étnica de sentido mais amplo na Bahia, um termo "guarda-chuva", contrariamente ao que representou no Rio de Janeiro. ${ }^{36}$ Em Salvador, no período de 1811-1830, Maria José Andrade constatou que a representação dos angolas foi de $11,7 \%$ no total da população cativa de origem africana, e foi o grupo mais representativo dentre os africanos centro-ocidentais, com $46,9 \%$, e de $68,7 \%$ para o período de 1831 1860. Em Rio de Contas, a nação angola foi, individualmente, a mais representativa dentre todas as naçōes, superando inclusive os minas. Contudo, devemos também considerar que, sob a denominação destas duas nações, poderiam estar incluídos indivíduos de outras nações. A preferência dos senhores de Rio de Contas pelos angolas e minas sugere que os escravistas do Alto Sertão da Bahia, até um determinado momento, adquiriram os escravos que estavam disponíveis no mercado de Salvador.

E, por fim, vejamos a configuração da categoria cor na composição da população cativa em Rio de Contas, no período de 1800-1850. No Brasil, além da origem e nação do escravo, a cor foi outro critério de classificação. Enquanto o termo preto indicava o natural da África, a expressão crioulo era comumente utilizada para o preto nascido no Brasil. ${ }^{37}$ Mariza Soares adverte para a abrangência do termo crioulo que, no século XVIII, designava os escravos nascidos no âmbito da sociedade colonial. ${ }^{38}$ Vale observar que não houve menção nas cartas de alforria e nem nos inventários pos-mortem a escravos nascidos na África com a designação de crioulos. Outras denominações eram usadas para os mestiços descendentes dos escravos nascidos na África. Antonio de Moraes Silva definiu, em seu dicionário, cabra como "o filho, ou filha, de pai mulato, e mãe preta, ou às avessas"; pardo como a pessoa "de cor entre branco e preto, como a do pardal". Já mulato ele atribuiu ao "filho, ou filha de preto com branca, ou às avessas, ou de mulato com branca"; e os mestiços como "o filho de europeu com índia, de branco com mulata" ${ }^{39}$ Essa terminologia racial, também presente na documentação cartorial, indicava não somente os matizes "de cor", mas também a condição jurídica do cativo. ${ }^{40}$

Dentre a população cativa nascida no Brasil em Rio de Contas, os crioulos representavam mais da metade, com 57,8\%. Os cabras formavam o segundo grupo mais representativo, com 22,9\%, seguidos de pardos $(9,7 \%)$, mulatos $(8,5 \%)$ e mestiços $(1,1 \%)$. Esses níveis diferentes de mestiçagem eram associados à condição jurídica do cativo, aproximando-o de um matiz "de cor" mais próximo à categoria do preto, caso do cativo crioulo, enquanto o liberto aproximava-se mais do universo da categoria do branco, caso dos mulatos, citados pelos viajantes, e dos pardos, alforriados em maior número, como veremos logo mais. Para Hebe Mattos, que estudou a região Sudoeste do Brasil na segunda metade do Oitocentos, "a noção de 'cor', herdada do período colonial, não designava, preferencialmente, matizes de pigmentação ou níveis diferentes de mestiçagem, mas buscava definir lugares sociais, nos quais etnia e condição estavam indissociavelmente ligadas". ${ }^{41} \mathrm{O}$ mesmo pode ser dito da primeira metade do século para muitos lugares do Brasil, inclusive Rio de Contas.

Em 1818, os viajantes Spix e Martius observaram que a população de algumas vilas do sertão era "formada na maioria por gente de cor" e, no município de Rio de Contas, salientaram a intensa miscigenação do seu povo, declarando que ali havia um grande número de mulatos, ressaltando o prestígio que estes desfrutavam. Quando passaram pela Cidade da Bahia, como Salvador era então conhecida, esses viajantes observaram que "as tonalidades mais leves da cor não fazem perder o prestígio na sociedade; há pessoas de cor distintamente mista, sem que isso cause estranheza, e somente para o estatístico será difícil determinar o limite entre os de cor e os brancos legítimos [...]”. ${ }^{42}$

Assim, uma das conclusões mais importantes sobre o estudo da composição demográfica da população cativa em Rio de Contas, entre 1800 e 1850, é o predomínio de escravos nascidos no Brasil em 
decorrência do declínio da importação de africanos. A crioulização demográfica da população cativa resultou em um maior equilíbrio entre os sexos, comparativamente ao ocorrido na população de origem africana. Entre os cativos desta origem, as nações numericamente mais representativas eram minas e angolas. Já a população de cativos nascidos no Brasil era formada, sobretudo, por crioulos. As razões para isso são, em parte, encontradas na alforria. A análise contemplou os dados até 1850, porque queríamos demonstrar que a crioulização demográfica se iniciara antes da proibição do tráfico transatlântico de escravos e porque, após esta data, informações sobre as nações começam a desaparecer na documentação. Na próxima seção, retomaremos os dados sobre a população cativa após este período, ao compararmos o desempenho de cativos africanos e nascidos no Brasil na conquista da alforria.

\section{Origem, nação e cor dos alforriados em Rio de Contas}

Em maio de 1843, na vila de Minas do Rio de Contas, Delmira, parda, comprou a sua alforria por $700 \$ 000$ réis. $^{43}$ No período de 1800 a 1850, os cativos nascidos no Brasil, como Delmira, beneficiaram-se das alforrias com uma larga vantagem em relação aos africanos. A análise da população forra indica que, para cada 549 cativos nascidos no Brasil, eram alforriados apenas 100 africanos. Por outro lado, a composição da população cativa no mesmo período demonstra que, para 300 cativos nascidos no Brasil, existiam 100 africanos. Como em outras regiōes do país, havia nessa região uma tendência maior de as alforrias beneficiarem os cativos nascidos no Brasil. Nesta seção, analisaremos o perfil dos alforriados em Rio de Contas segundo a origem, nação, cor e sexo, nos períodos de 1800-1850, 1850-1871 e 1871-1888, comparando-o com outras regiōes da Bahia e, sempre que possível, do Brasil.

No município de Rio de Contas, por todo o período de 1800-1888, os cativos nascidos no Brasil superaram em número os de origem africana, mesmo antes da proibição do tráfico. Após 1851, com a extinção do tráfico transatlântico, o número de africanos declinou gradualmente, acentuando-se após 1871.

Os escravos nascidos no Brasil se saíram melhor do que os africanos na conquista da liberdade: representavam 77,3\% dos que conseguiam ultrapassar o cativeiro no período de 1800 a 1850. Após a extinção do tráfico transatlântico continuaram alcançando expressiva vantagem: eram $79,2 \%$ no período de 1850 a 1871 e $62,6 \%$ no período de 1871 a 1888 . Vale ressaltar que a diminuição dos índices de crioulos alforriados no último período deveu-se à designação da variável "cor" do forro nas cartas de alforria que, a partir de então, passaram também a denominá-lo "preto", sem esclarecer se era africano ou nascido no Brasil. Ao estudar os negros ganhadores, escravos e libertos, que se dedicavam ao trabalho de rua, no final da década de $1880 \mathrm{em}$ Salvador, Reis constatou a ausência do termo crioulo. O autor chama a atenção para o fato de que preto, naquele momento, podia indicar tanto o negro nascido na África quanto no Brasil. O crioulo, afirma o autor, "ao passar a ser chamado como antes eram chamados os africanos, sofreu uma espécie de africanização no sistema de classificação racial hegemônico". ${ }^{4}{ }^{4}$

Comparando a vantagem dos nascidos no Brasil na obtenção da alforria, verificamos que isso não foi específico de Rio de Contas. Andréa Gonçalves, ao estudar a prática de alforria em Ouro Preto, chegou a resultados semelhantes, isto é, os nascidos no Brasil (70,9\%) foram também os mais beneficiados pela alforria. ${ }^{45}$

Já Kátia Mattoso constatou que, em Salvador, na primeira metade do século XIX, o percentual de forros nascidos no Brasil oscilou entre $40 \%$ e $55 \%$, o que, para ela, "demonstra um certo equilíbrio entre estes e aqueles outros nascidos na África". As diferenças por ela apuradas foram somente para o biênio 1809-1810, com uma elevação em favor dos nascidos no Brasil e, também para o biênio 1829-1830, quando a alforria pendeu para os cativos de origem africana, que superavam os nascidos no Brasil devido às contínuas importações. ${ }^{46}$ Mas Mieko Nishida chega a conclusões diferentes: em todo o período de 1808-1884, os nascidos no Brasil levaram vantagem sobre os de origem africana, porém, a análise de períodos mais curtos indica variações. Nas três primeiras décadas do século XIX, apesar de os cativos africanos residentes em Salvador excederem numericamente os nascidos no Brasil, na razão de 2:1, houve um 
maior número de alforriados entre os nascidos no Brasil. Já no período de 1831-1852, Nishida verificou que um maior número de africanos obteve a sua alforria. ${ }^{47}$ Importa salientar que, por toda a primeira metade do século XIX, a maioria da população cativa de Salvador era composta por africanos. ${ }^{48}$

Dentre os alforriados oriundos da África, existentes no município de Rio de Contas na primeira metade do século XIX, houve certo equilíbrio entre os cativos que procediam da África Ocidental e da África Centro-Ocidental.

A análise relativa às nações que mais se beneficiaram com a alforria demonstra que os minas e angolas se saíram melhor. Como se vê na Tabela 2, a população cativa procedente da África Centro-Ocidental estava menos representada (32,7\%) comparativamente aos nascidos na África Ocidental (51\%), com uma diferença de 18,3\% a favor desta. Mas, no momento de obter a liberdade, os africanos centro-ocidentais diminuíram essa disparidade para 5,9\%. Porém, isoladamente, o desempenho da nação mina $(33,3 \%)$ foi um pouco maior que o da nação angola $(30,4 \%)$.

Tabela 2 - População forra e cativa de origem africana em

Rio de Contas, segundo o sexo e a nação (1800-1850)

\begin{tabular}{|c|c|c|c|c|c|c|c|c|c|c|c|c|}
\hline \multicolumn{7}{|c|}{ População Forra } & \multicolumn{6}{|c|}{ População Cativa } \\
\hline \multirow{2}{*}{ África Ocidental } & \multicolumn{2}{|c|}{ Homens } & \multicolumn{2}{|c|}{ Mulheres } & \multicolumn{2}{|c|}{ Total } & \multicolumn{2}{|c|}{ Homens } & \multicolumn{2}{|c|}{ Mulheres } & \multicolumn{2}{|c|}{ Total } \\
\hline & $\mathrm{N}$ & $\%$ & $\mathrm{~N}$ & $\%$ & $\mathrm{~N}$ & $\%$ & $\mathrm{~N}$ & $\%$ & $\mathrm{~N}$ & $\%$ & $\mathrm{~N}$ & $\%$ \\
\hline Mina & 27 & 36,0 & 18 & 30,0 & 45 & 33,3 & 48 & 19,8 & 30 & 29,4 & 78 & 22,6 \\
\hline Haussá & 3 & 4,0 & & & 3 & 2,2 & 25 & 10,3 & 8 & 7,8 & 33 & 9,6 \\
\hline Calabar & 2 & 2,7 & & & 2 & 1,5 & 19 & 7,9 & 18 & 17,6 & 37 & 10,7 \\
\hline Nagô & 1 & 1,3 & 2 & 3,3 & 3 & 2,2 & 19 & 7,9 & 4 & 3,9 & 23 & 6,6 \\
\hline Outras naçōes* & & & 2 & 3,3 & 2 & 1,5 & 3 & 1,2 & 2 & 2,0 & 5 & 1,5 \\
\hline Subtotal & 33 & 44,0 & 22 & 36,6 & 55 & 40,7 & 114 & 47,1 & 62 & 60,8 & 176 & 51,0 \\
\hline \multirow{2}{*}{$\begin{array}{l}\text { África Centro } \\
\text { Ocidental }\end{array}$} & \multicolumn{2}{|c|}{ Homens } & \multicolumn{2}{|c|}{ Mulheres } & \multicolumn{2}{|c|}{ Total } & \multicolumn{2}{|c|}{ Homens } & \multicolumn{2}{|c|}{ Mulheres } & \multicolumn{2}{|c|}{ Total } \\
\hline & $\mathrm{N}$ & $\%$ & $\mathrm{~N}$ & $\%$ & $\mathrm{~N}$ & $\%$ & $\mathrm{~N}$ & $\%$ & $\mathrm{~N}$ & $\%$ & $\mathrm{~N}$ & $\%$ \\
\hline Angola & 22 & 29,3 & 19 & 31,7 & 41 & 30,4 & 64 & 26,4 & 22 & 21,6 & 86 & 24,9 \\
\hline Benguela & 2 & 2,7 & & & 2 & 1,5 & 11 & 4,5 & & & 11 & 3,2 \\
\hline Congo & 2 & 2,7 & 1 & 1,7 & 3 & 2,2 & 6 & 2,5 & 1 & 1,0 & 7 & 2,0 \\
\hline Cabinda & & & & & & & 5 & 2,1 & & & 5 & 1,4 \\
\hline Outras naçōes** & & & 1 & 1,7 & 1 & 0,7 & 4 & 1,7 & & & 4 & 1,2 \\
\hline Subtotal & 26 & 34,7 & 21 & 35,1 & 47 & 34,8 & 92 & 38,0 & 23 & 22,5 & 113 & 32,7 \\
\hline \multirow{2}{*}{ África Oriental } & \multicolumn{2}{|c|}{ Homens } & \multicolumn{2}{|c|}{ Mulheres } & \multicolumn{2}{|c|}{ Total } & \multicolumn{2}{|c|}{ Homens } & \multicolumn{2}{|c|}{ Mulheres } & \multicolumn{2}{|c|}{ Total } \\
\hline & $\mathrm{N}$ & $\%$ & $\mathrm{~N}$ & $\%$ & $\mathrm{~N}$ & $\%$ & $\mathrm{~N}$ & $\%$ & $\mathrm{~N}$ & $\%$ & $\mathrm{~N}$ & $\%$ \\
\hline Moçambique & & & & & & & 2 & 0,8 & & & 2 & 0,6 \\
\hline Não-identificada & 16 & 21,3 & 17 & 28,3 & 33 & 24,5 & 36 & 14,9 & 18 & 16,7 & 54 & 15,7 \\
\hline Total & 75 & 100 & 60 & 100 & 135 & 100 & 242 & 100 & 103 & 100 & 345 & 100 \\
\hline
\end{tabular}

Fonte: AMRC, Livros de Notas do Tabelionato e inventários post-mortem. As cartas de alforria foram estudadas em sua totalidade, já a amostra de população cativa se baseia em lista de escravos inventariados, sendo levantada a totalidade dos documentos do triênio de cada uma das décadas compreendidas no periodo de 1800 a 1850. Do universo de 960 alforriados nesse periodo, não foram identificadas a origem para 82 casos.

* População cativa inclui: 2 tapas, 2 benin e 1 jeje; população forra inclui: 1 jeje e 1 benin.

** População cativa inclui: 1 cassange e 3 monjolo; população forra inclui: 1 rebolo.

Entre os angolas, as mulheres foram, proporcionalmente, as mais beneficiadas: apesar de quantitativamente serem inferiores na população cativa, com aproximadamente $21,6 \%$, correspondem a $31,7 \%$ das alforriadas; porém, muitas vezes, por razões que tornam o benefício duvidoso. Esse foi o caso de Maria, angola, que foi alforriada "por ser já de idade avançada e achacada de várias moléstias e pelos bons serviços prestados" ${ }^{49}$ Assim, a idade avançada pode ser uma explicação plausível para o desempenho 
das mulheres desta nação, apesar de a maioria das cartas serem omissas no tocante a esta variável. Os homens da nação angola não tiveram o mesmo desempenho que as mulheres, apesar da pequena vantagem de $2,9 \%$ comparativamente ao que representavam na população cativa. Isso pode significar que as mulheres, por serem em grande número domésticas, gozavam da intimidade e afeição de senhores que as recompensavam com alforrias ao contrário dos homens que, em geral, não eram gente da casa.

Os homens de nação mina, apesar de menos representados na população cativa, foram mais privilegiados com a alforria, com a diferença de $16,2 \%$ do que representavam na população cativa. Já entre as mulheres desta nação, não houve oscilação significativa. Em 73,3\% dos casos, os cativos da nação mina compraram a liberdade, sendo que, dos pagamentos identificados, $80 \%$ foi feito pelo próprio escravo.

Os cativos de nação mina também foram mais beneficiados no momento da alforria no Rio de Janeiro, onde Manolo Florentino constatou que os desta nação, apesar de menos representativos na população cativa, eram mais privilegiados no momento da alforria. Os cativos de nação mina no Rio de Janeiro obtinham suas alforrias mediante a compra, e para isto contribuía a sua grande participação entre os cativos de ganho. ${ }^{50}$ Contudo, é Sheila de Castro Faria quem nos esclarece a participação por sexo entre os minas alforriados do Rio de Janeiro: às mulheres mais do que aos homens, coube essa vantagem. ${ }^{51}$

As ocupações exercidas pelos cativos, sem sombra de dúvida, significaram um grande diferencial no momento da aquisição da liberdade. Dados sobre ocupação exercida pelos escravos, em Rio de Contas, podem revelar o porquê da vantagem no momento da alforria, mas as informações constantes dos registros de alforria são esporádicas. Por outro lado, para as nações numericamente predominantes, minas e angolas, havia uma imprecisão de terminologia, o que dificulta uma análise da maior aptidão dos indivíduos de certas naçôes a alcançarem sua liberdade.

Em Salvador, nesse mesmo período, Mattoso encontrou que os nagôs $(28,3 \%)$ predominaram nas alforrias, seguidos dos jejes $(26,9 \%)$ e minas $(20,2 \%) .^{52}$ Já Nishida pondera que havia uma correspondência geográfica e étnica entre os escravos comprados e vendidos na freguesia da Sé e os forros nascidos na África, concluindo que "as origens geográficas ou étnicas não foram fatores determinantes na obtenção da liberdade no caso do escravo africano considerado individualmente".${ }^{53}$ Em Rio de Contas, vimos que minas e angolas, duas naçôes "guarda-chuva", foram as mais representativas tanto na população cativa quanto na forra. A vantagem dos cativos de nação mina, de ambos os sexos, aumentou em 10,7\% no momento da alforria e a dos angolas, em 5,5\%, comparativamente ao que representavam na população cativa.

Para o período de 1850-1871, constatamos que a análise fica prejudicada porque, a partir de então, as informações sobre a origem étnica dos escravos começaram a rarear na documentação, desaparecendo por completo no período entre 1871 e $1888 .{ }^{54} \mathrm{O}$ cativo estrangeiro passa a ser chamado, genericamente, de africano. Em Salvador, Nishida observou que, "no período de 1851-1884, menos da metade $(48,8 \%)$ dos forros de origem africana foi identificada por 'nação' nas cartas de alforria". ${ }^{55}$ Podemos apenas comparar o conjunto dos africanos com o conjunto dos nascidos no Brasil, o que faremos adiante.

Vejamos agora o desempenho entre os cativos nascidos no Brasil. Em Rio de Contas, a cor indicava uma maior ou menor proximidade da condição de liberdade. Os cativos mulatos e os pardos foram largamente favorecidos, como Maria, mulata, que comprou sua alforria por $160 \$ 000$, ou Esméria, parda, alforriada gratuitamente "pelo amor de ser minha cria". ${ }^{56} \mathrm{Na}$ primeira metade do século XIX, os mulatos foram $11,9 \%$ mais beneficiados, e os pardos, $9 \%$, em comparação com a proporção que representavam na população cativa nascida no Brasil. Já os crioulos sofreram um declínio de 18\%, comparado ao que representavam na população cativa (Tabela 3). 
Tabela 3 - População forra e cativa nascidas no Brasil em Rio de Contas, segundo sexo e cor (1800-1850)

\begin{tabular}{|l|c|c|c|c|c|c|c|c|c|c|c|c|}
\hline & \multicolumn{4}{|c|}{ População Forra } & \multicolumn{5}{c|}{ População Cativa } \\
\cline { 2 - 17 } & \multicolumn{2}{|c|}{ Homens } & \multicolumn{2}{c|}{ Mulheres } & \multicolumn{2}{c|}{ Total } & \multicolumn{2}{c|}{ Homens } & \multicolumn{2}{c|}{ Mulheres } & \multicolumn{2}{c|}{ Total } \\
\cline { 2 - 15 } & $\mathrm{N}$ & $\%$ & $\mathrm{~N}$ & $\%$ & $\mathrm{~N}$ & $\%$ & $\mathrm{~N}$ & $\%$ & $\mathrm{~N}$ & $\%$ & $\mathrm{~N}$ & $\%$ \\
\hline Crioulo & 127 & 43,2 & 169 & 37,6 & 296 & 39,9 & 340 & 60,8 & 259 & 54,4 & 599 & 57,9 \\
\hline Cabra & 61 & 20,7 & 88 & 19,6 & 149 & 20,1 & 134 & 24,0 & 103 & 21,6 & 237 & 22,9 \\
\hline Pardo & 58 & 19,7 & 82 & 18,3 & 139 & 18,8 & 44 & 7,9 & 56 & 11,8 & 100 & 9,7 \\
\hline Mulato & 45 & 15,3 & 106 & 23,6 & 151 & 20,3 & 36 & 6,4 & 52 & 10,9 & 88 & 8,5 \\
\hline Mestiço & 3 & 1,0 & 4 & 0,9 & 7 & 0,9 & 5 & 0,9 & 6 & 1,3 & 11 & 11,1 \\
\hline Total & 294 & 100 & 449 & 100 & 743 & 100 & 559 & 100 & 476 & 100 & 1035 & 100 \\
\hline
\end{tabular}

Fonte: ver Tabela 2.

A relação entre cor e faixa etária pode fornecer outra perspectiva de análise. Antes é necessário advertir que esta não foi uma variável constante nas cartas de alforria, sobretudo no período 1800-1850.57 A maior incidência de alforria foi na faixa etária de 0 a 12 anos, com 48,5\%. Nesta faixa de idade, os mulatos foram imbatíveis, com $29,4 \%$ de vantagem em relação ao que representavam na população cativa, e os pardos ficaram em $8,6 \%$, proporcionalmente ao seu número na população cativa. Já entre os cativos adultos, os pardos foram os que mais se beneficiaram com a alforria, com uma vantagem de $7,3 \%$, comparativamente ao que representavam na população cativa. Contudo, os cativos adultos mulatos $(3,1 \%)$ não tiveram a representatividade das crianças de mesma cor, ficando, inclusive, um pouco abaixo dos cabras (4,8\%). Desta forma, a vantagem dos mulatos e pardos se deve, em grande medida, à alforria de crianças, que era em número proporcionalmente alto comparando com a população cativa adulta na faixa de 13 a 45 anos.

Não foi possível comparar nossos dados com os de Andréa Gonçalves para Ouro Preto, porque ela não faz uma análise segundo o critério de cor. Mas o trabalho de Katheleen Higgins, para Sabará setecentista, confirma uma preferência grande por mulatos e pardos entre os alforriados, tendência que se acentua para as crianças. ${ }^{58}$ Em Salvador, Nishida constatou que estas duas categorias de cor foram preferidas dentre os cativos, sendo que os mulatos tiveram 9,2\% mais oportunidades de obterem a alforria, e os pardos, 8,5\%.59 Para Peter Eisenberg e Higgins, a sociedade, naquele período, tendia a associar cor à condição jurídica do indivíduo, ou seja, aos fenótipos dos pardos e mulatos, devido à semelhança com os portugueses. Além disso, por muitos desses cativos serem cria de casa e filhos de senhores, eram favorecidos nos momentos da alforria. ${ }^{60}$

Em Rio de Contas, no período de 1850 a 1871, os pardos e mulatos continuaram se destacando como os mais beneficiados com a alforria, sendo que a vantagem dos pardos foi de $13 \%$, e a dos mulatos, de 9,5\% (Tabela 4). Nesse período, observamos que a faixa etária entre 0 e 12 anos de idade continuou com os maiores índices de alforria, embora houvesse uma diminuição em relação ao período anterior. Considerando todos os cativos de cor nessa faixa de idade, verificamos que os pardos saíram na frente com $45,8 \%$ e os mulatos ficaram um pouco abaixo, com $19,4 \%$. Confrontando estes dados com aqueles verificados na população cativa, notamos que a vantagem das crianças pardas foi de $26,6 \%$, e a das mulatas foi de $17,7 \%$. Já entre os cativos adultos, os pardos continuaram com vantagem $(11,9 \%)$ em relação aos demais cativos, inclusive os mulatos $(3,8 \%)$. 
Tabela 4 - População forra e cativa nascidas no Brasil em Rio de Contas, segundo sexo e cor (1850-1871)

\begin{tabular}{|l|c|c|c|c|c|c|c|c|c|c|c|c|}
\hline \multirow{4}{*}{} & \multicolumn{9}{|c|}{ População Forra } & \multicolumn{5}{c|}{ População Cativa } \\
\cline { 2 - 16 } & \multicolumn{2}{|c|}{ Homens } & Mulheres* & \multicolumn{2}{c|}{ Total } & \multicolumn{2}{c|}{ Homens } & \multicolumn{2}{c|}{ Mulheres } & \multicolumn{2}{c|}{ Total } \\
\cline { 2 - 15 } & $\mathrm{N}$ & $\%$ & $\mathrm{~N}$ & $\%$ & $\mathrm{~N}$ & $\%$ & $\mathrm{~N}$ & $\%$ & $\mathrm{~N}$ & $\%$ & $\mathrm{~N}$ & $\%$ \\
\hline Crioulo & 42 & 32,6 & 68 & 33,8 & 110 & 33,3 & 133 & 54,7 & 120 & 47,8 & 253 & 51,2 \\
\hline Cabra & 31 & 24,0 & 45 & 22,4 & 76 & 23,0 & 64 & 26,3 & 77 & 30,7 & 141 & 28,5 \\
\hline Pardo & 43 & 33,3 & 58 & 28,9 & 101 & 30,6 & 41 & 16,9 & 46 & 18,3 & 87 & 17,6 \\
\hline Mulato & 12 & 9,3 & 28 & 13,9 & 40 & 12,1 & 5 & 2,1 & 8 & 3,2 & 13 & 2,6 \\
\hline Mestiço & 1 & 0,8 & 1 & 0,5 & 2 & 0,6 & & & & & & \\
\hline Branco & & & 1 & 0,5 & 1 & 0,3 & & & & & & \\
\hline Total & 129 & 100 & 201 & 100 & 330 & 100 & 243 & 100 & 251 & 100 & 494 & 100 \\
\hline
\end{tabular}

Fonte: ver Tabela 2. *Não foi possivel identificar duas forras nascidas no Brasil pela categoria cor, pois as cartas mencionavam apenas a naturalidade. Do universo de 419 alforriados, 33 eram naturais da África; e em 54 deles, a origem não foi informada.

Em Salvador, Nishida, analisando o período de 1852 a 1888, obteve os seguintes resultados: os pardos continuaram sendo beneficiados à razão de $9,3 \%$, mas a vantagem dos mulatos foi de apenas $0,6 \%$ em relação à população cativa. Já a desvantagem dos crioulos e cabras diminuiu em relação ao período anterior, o que não ocorreu em Rio de Contas. ${ }^{61}$

No último período analisado, 1871 a 1888 , em Rio de Contas, os crioulos se destacaram com $14,1 \%$ (Tabela 5). Esta vantagem se estende a todas as faixas de idade: crianças (18,4\%), adultos (12\%), e idosos (17,6\%). A vantagem dos cabras foi de 7,5\%, sendo maior entre as crianças. As duas categorias não estão presentes no censo realizado em 1872 . Neste censo, a população escrava, que representava $15 \%$ da população do município de Rio de Contas, não foi distinguida pela categoria "cor", mas, na população como um todo, essa distinção foi: brancos, 32\%; pardos, 49\%; pretos, 17,9\% e caboclos, $1,1 \% .{ }^{62}$ Os identificados como pretos tiveram uma desvantagem de $21,8 \%$ na alforria. Conforme referimos anteriormente, "preto", a partir de 1871, passou também a designar o cativo nascido no Brasil.

Tabela 5 - População forra e cativa em Rio de Contas, segundo sexo e cor (1871-1888)

\begin{tabular}{|l|c|c|c|c|c|c|c|c|c|c|c|c|}
\hline & \multicolumn{4}{|c|}{ População Forra } & \multicolumn{5}{c|}{ População Cativa } \\
\cline { 2 - 17 } & \multicolumn{2}{|c|}{ Homens } & \multicolumn{2}{|c|}{ Mulheres } & \multicolumn{2}{c|}{ Total } & \multicolumn{2}{c|}{ Homens } & \multicolumn{2}{c|}{ Mulheres } & \multicolumn{2}{c|}{ Total } \\
\cline { 2 - 16 } & $\mathrm{N}$ & $\%$ & $\mathrm{~N}$ & $\%$ & $\mathrm{~N}$ & $\%$ & $\mathrm{~N}$ & $\%$ & $\mathrm{~N}$ & $\%$ & $\mathrm{~N}$ & $\%$ \\
\hline Preto & 32 & 22,5 & 51 & 27,1 & 83 & 25,2 & 101 & 46,4 & 102 & 47,6 & 203 & 47,0 \\
\hline Crioulo & 31 & 21,8 & 27 & 14,4 & 58 & 17,6 & 9 & 4,2 & 6 & 2,7 & 15 & 3,5 \\
\hline Cabra & 21 & 14,8 & 26 & 13,8 & 47 & 14,2 & 16 & 5,9 & 13 & 7,5 & 29 & 6,7 \\
\hline Pardo & 52 & 36,6 & 78 & 41,5 & 130 & 39,4 & 86 & 40,6 & 99 & 45,0 & 185 & 42,8 \\
\hline Mulato & 6 & 4,2 & 6 & 3,2 & 12 & 3,6 & & & & & & \\
\hline Total & 142 & 100 & 188 & 100 & 330 & 100 & 212 & 100 & 220 & 100 & 432 & 100 \\
\hline
\end{tabular}

Fonte: ver Tabela 2. Do universo de 398 alforriados neste periodo, em 68 deles não foi possivel identificar a cor.

Nesse último período, a vantagem dos cativos acima de 46 anos em alcançar a alforria cresceu em 17,9\%, comparativamente ao seu percentual na população cativa. Por outro lado, o acesso à liberdade para aqueles com idade entre 0 e 12 anos diminuiu em relação ao período anterior, porque a maioria já estava contemplada pela lei de 1871 e, portanto, não aparece nas alforrias. 
Podemos também comparar a origem do alforriado com o tipo de alforria que possibilita mensurar se os escravos de origem africana e os nascidos no Brasil tinham iguais oportunidades de alforria. ${ }^{63}$

Se compararmos o contingente de escravos de origem africana existente na população cativa, no período de 1800 a 1850 , que representava $23,4 \%$, com o número de forros de origem africana, que era de $14,1 \%$, fica evidente que a origem foi um fator importante na obtenção da alforria, ou seja, o africano obtinha 9,3\% menos de alforria do que o esperado. Os cativos nascidos no Brasil foram imbatíveis em todos os tipos de alforria, o que não é novidade dada a sua superioridade demográfica no município de Rio de Contas. Contudo, é interessante considerarmos as maneiras como africanos e nascidos no Brasil interagiam com os diferentes tipos de alforria ao longo do século XIX.

No povoado de Santo Antônio da Gota, distrito de Rio de Contas, em setembro de 1817, José, mina, obteve sua carta de liberdade por $130 \$ 000$, pagando-a, ele mesmo, ao casal Paula de Souza Pires e Felippe Domingues Alam. ${ }^{64}$ Essa era a forma mais usual de os cativos de origem africana conseguirem a alforria, enquanto que, entre os nascidos no Brasil, essa via superou as demais somente no primeiro período. É inquestionável que o acesso ao pecúlio representou uma limitação para os escravos nascidos no Brasil obterem a liberdade; porém, muito mais para os africanos. Ainda que o pagamento fosse a mais importante via de acesso à liberdade, os cativos nascidos no Brasil contavam mais frequentemente com a ajuda de suas mães, de seus pais, filhos, maridos, avós, madrinhas/padrinhos, e também de terceiros. Isto porque eles, supostamente, tinham, mais do que os africanos, laços familiares e de compadrio com os livres.

Tabela 6 - Tipos de alforria e origem dos alforriados em Rio de Contas (1800-1888)

\begin{tabular}{|l|c|c|c|c|c|c|c|c|}
\hline \multirow{2}{*}{$1800-1850^{*}$} & \multicolumn{7}{|c|}{ África Brasil total 2} \\
\cline { 2 - 10 } & $\mathrm{N}$ & $\% 1$ & $\% 2$ & $\mathrm{~N}$ & $\% 1$ & $\% 2$ & $\mathrm{~N}$ & $\%$ \\
\hline Paga e incondicional & 70 & 51,9 & 19,9 & 281 & 38,0 & 80,1 & 351 & 100 \\
\hline Gratuita & 20 & 14,8 & 8,3 & 222 & 30,0 & 91,7 & 242 & 100 \\
\hline Não paga e condicional & 29 & 21,5 & 13,1 & 192 & 25,9 & 86,9 & 221 & 100 \\
\hline Paga e condicional & 16 & 11,9 & 26,2 & 45 & 6,1 & 73,8 & 61 & 100 \\
\hline Total 1 & 135 & 100 & 15,4 & 740 & 100 & 84,6 & 875 & 100 \\
\hline \multirow{7}{*}{ 1850-1871 } & \multicolumn{7}{|c|}{ África Brasil total 2 } \\
\cline { 2 - 11 } & $\mathrm{N}$ & $\% 1$ & $\% 2$ & $\mathrm{~N}$ & $\% 1$ & $\% 2$ & $\mathrm{~N}$ & $\%$ \\
\hline Paga e incondicional & 15 & 45,5 & 11,7 & 113 & 34,0 & 88,3 & 128 & 100 \\
\hline Gratuita & 6 & 18,2 & 8,0 & 69 & 20,8 & 92,0 & 75 & 100 \\
\hline Não paga e condicional & 11 & 33,3 & 7,9 & 129 & 38,9 & 92,1 & 140 & 100 \\
\hline Paga e condicional & 1 & 3,0 & 4,5 & 21 & 6,3 & 95,5 & 22 & 100 \\
\hline Total 1 & 33 & 100 & 9,0 & 332 & 100 & 91,0 & 365 & 100 \\
\hline \multirow{2}{*}{ 1871-1888** } & \multicolumn{7}{|c|}{ África Brasil total 2 } & \\
\cline { 2 - 10 } & $\mathrm{N}$ & $\% 1$ & $\% 2$ & $\mathrm{~N}$ & $\% 1$ & $\% 2$ & $\mathrm{~N}$ & $\%$ \\
\hline Paga e incondicional & 11 & 50,0 & 14,7 & 64 & 25,7 & 85,3 & 73 & 100 \\
\hline Gratuita & 7 & 31,8 & 10,3 & 61 & 24,5 & 89,7 & 68 & 100 \\
\hline Não paga e condicional & 3 & 13,6 & 2,4 & 120 & 48,2 & 97,6 & 123 & 100 \\
\hline Paga e condicional & 1 & 4,5 & 20,0 & 4 & 1,6 & 80,0 & 5 & 100 \\
\hline Total 1 & 22 & 100 & 8,1 & 249 & 100 & 91,9 & 271 & 100 \\
\hline
\end{tabular}

Fonte: $A M R C$, Livros de Notas do Tabelionato.

* Em três cartas não foi possivel identificar o tipo de alforria.

** Para 127 alforrias, do total de 398, não havia informação para a origem. 
Como já dissemos anteriormente, os cativos nascidos no Brasil superaram os africanos no que se refere às manumissões gratuitas. Contudo, essa via de acesso à liberdade foi, a partir do segundo período, uma das formas mais frequentes de os africanos alcançarem-na. A explicação para tal mudança pode estar na idade avançada dos africanos no segundo e, sobretudo, no último período analisado. Assim, à medida que os africanos envelheciam, seu acesso à liberdade gratuita tornou-se mais frequente. Entre os cativos nascidos no Brasil, a gratuidade ocupou o segundo lugar no acesso à alforria apenas no primeiro período, passando a um mero terceiro lugar nos dois últimos períodos. Vale lembrar que, a partir de 1850, os senhores ficaram mais cautelosos quando se tratava de alforriar um cativo gratuitamente. Todavia, o fato de este índice não ter decrescido abruptamente demonstra como a alforria era parte importante na política de domínio senhorial. A alforria gratuita era utilizada para agregar libertos dependentes.

No que se refere às cartas que impunham condiçôes e, considerando o primeiro e o segundo períodos, os africanos tiveram o segundo melhor desempenho. Outrossim, a partir de 1850, o desempenho dos nascidos no Brasil no tocante a este tipo de alforria aumentou significativamente. As dificuldades de acesso dos cativos, inclusive dos nascidos no Brasil, ao mundo dos livres aumentaram após 1850. Esse tipo de alforria foi uma forma de os senhores reterem e controlarem a mão de obra cativa. A condição mais frequente no período entre 1850 e 1871 foi a de o escravo(a) servir até a morte do senhor. Após a Lei do Ventre Livre, além dessa condição persistir, houve um aumento da condição de trabalho por tempo determinado. Contudo, não detectamos nas cartas de alforria analisadas "a prática de remunerar os serviços prestados por alforriados", como foi constatado por Peter Eisenberg para Campinas. ${ }^{65}$

Enfim, a liberdade era mais acessível quando se podia negociar com dinheiro ou mercadoria, e que, em contrapartida, o acesso à liberdade condicional e gratuita era muito mais penoso, pois poderia significar a permanência dos vínculos entre o senhor e o escravo por longos anos de relações de dependência e obediência, ainda que a alforria paga e incondicional nem sempre significasse o rompimento de tais vínculos. Examinemos agora como homens e mulheres se diferenciavam na corrida para a alforria.

A categoria sexo nas cartas de alforria

A historiografia é unânime em afirmar a maior presença das mulheres no conjunto dos alforriados. Por isso, analisaremos a seguir a preponderância relativa das mulheres entre os forros de Rio de Contas, o cotejamento com outras regiōes, bem como algumas hipóteses explicativas deste predomínio.

Em Rio de Contas, as mulheres ganham para os homens em todos os períodos considerados. Entre 1800 e 1850, houve maior incidência das mulheres no conjunto dos escravos nascidos no Brasil alforriados (152 mulheres para 100 homens), e dos homens entre os de origem africana (125 homens para 100 mulheres). Mas ao considerarmos o conjunto desses alforriados, verificamos que a presença dos forros do sexo masculino diminuiu em função da maior presença das cativas nascidas no Brasil. A análise dos forros por sexo, de acordo com os dados reproduzidos no gráfico 1, indica que, no período de 1800-1850, essa proporção foi de 140 mulheres para 100 homens; de 1850 a 1871, de 142 mulheres para 100 homens e, no último período estudado, 1871 a 1888, essa razão foi de 130 mulheres para 100 homens. Uma vez que na população cativa houve o predomínio do sexo masculino (1800-1850) ou o equilíbrio entre os sexos (1850-1888), conforme o gráfico 2, a presença das mulheres no conjunto dos alforriados corrobora o que a historiografia constatou para outras regióes, não obstante as nuanças da categoria cor, como veremos logo mais. 
Gráfico 1 - Sexo dos forros por período

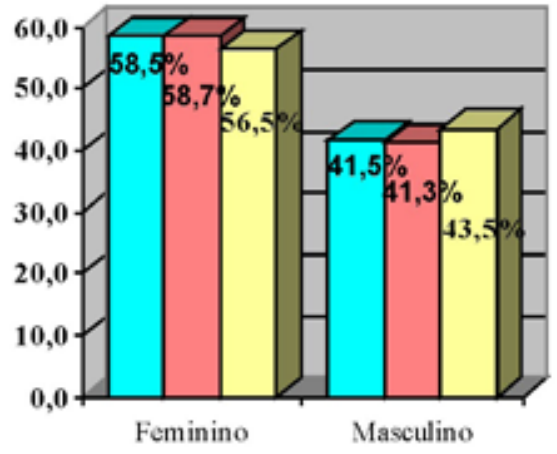

Fonte: AMRC, Livro de Notas do Tabeliāo, 1800-1888.

Gráfico 2 - Sexo dos cativos por período

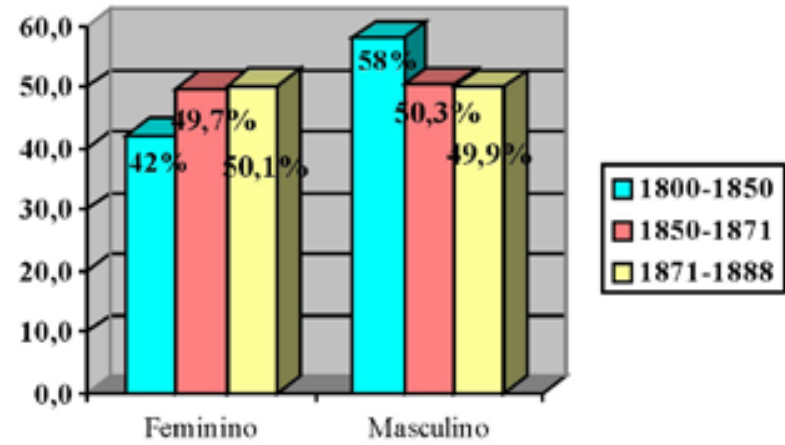

Fonte: AMRC, Inventários post-mortem, 1800-1888.

A tendência a libertar, em maior número, escravos do sexo feminino foi também verificada em Ouro Preto, onde Gonçalves registrou que, de 1800 a 1870, a proporção entre os forros de origem africana foi de 111,8 homens para 100 mulheres. Nesta mesma região, entre os nascidos no Brasil, essa razão foi de 141 mulheres para 100 homens, e a razão no conjunto dos forros foi de 123 mulheres para 100 homens. Isto significa que, naquela região, a exemplo de Rio de Contas, eram as mulheres nascidas no Brasil que promoviam o desequilíbrio entre os sexos a favor das mulheres na população liberta. Para Gonçalves, havia a expectativa de que o predomínio da alforria entre as mulheres decrescesse "à medida que a população crioulizava-se, em que se verificassem alterações nas atividades produtivas desempenhadas pelos escravos e em que avançassem os questionamentos gerais quanto à conveniência de manutenção da instituição servil". ${ }^{66}$ Ocorre que a variável sexo é relativamente independente da variável origem: as mulheres tinham melhor desempenho independente de onde nasciam. Houve, porém, oscilações em torno desse tema.

Para Mattoso, a preferência em alforriar mulheres em Salvador explica-se porque "de ordinário, vivem na intimidade do senhor ou exercem o ofício de vendedoras ambulantes. Além disso, custa menos substituí-las, e elas envelhecem mais depressa que os homens". ${ }^{67}$ Já Nishida constatou que "as escravas beneficiaram-se da alforria com frequência apenas um pouco maior do que os escravos, à razão de 57:43", ou seja, 132 mulheres para cada 100 homens. ${ }^{68}$ Ela atribui esta tendência ao fato de esses cativos viverem em um ambiente urbano e por trabalharem no sistema "de ganho", o que lhes proporcionava mais ocasiōes de acumular dinheiro e assim comprar sua liberdade, diferentemente das áreas de grande lavoura. Entre os africanos, a razão entre homens e mulheres foi mais equilibrada, enquanto, entre os nascidos no Brasil, as mulheres foram dois terços mais beneficiadas que os homens. 
Nishida ponderou que o predomínio significativo das mulheres em alguns períodos, como 18511852, deveu-se a fatores econômicos - como a demanda por mão de obra masculina na agricultura -, o que dificultaria a esses cativos o acesso à liberdade, pelo aumento do seu valor de mercado. Por outro lado, na última década da escravidão, a proporção de alforrias de africanos do sexo masculino aumentou em decorrência da idade avançada, que os impossibilitava de continuar trabalhando, ao passo que as mulheres cativas de mesma origem continuaram exercendo tarefas domésticas, ainda que idosas. Neste aspecto, como em outros, Nishida contesta dados e interpretaçôes de Mattoso.

As cartas de alforrias em Rio de Contas indicam que não houve correspondência entre o sexo da população cativa e o da população forra, pois, durante os períodos analisados, a alforria continuou privilegiando a mulher. Todavia, a variável cor comparada ao sexo indica que nem todas as mulheres foram favorecidas no momento da alforria. No período de 1800 a 1850, as crioulas, que, proporcionalmente, foram o grupo mais representativo na população cativa, continuaram com grande expressão no grupo das forras, embora tenham declinado em 16,7\%, comparativamente ao que representavam na população cativa. Vale ressaltar que os homens crioulos levaram uma pequena vantagem em relação às mulheres. As mulheres cabras forras, por sua vez, também não levaram vantagem por ocasião da alforria, empatando tecnicamente com os homens da mesma cor. Já as pardas foram beneficiadas comparativamente à sua proporção na população cativa; porém, a vantagem dos pardos forros foi maior, em torno de $11,8 \%$. As mais beneficiadas, nesse primeiro período, foram as mulatas, cuja representação na população forra foi 12,8\% maior em relação à população cativa. Além disso, a sua vantagem em relação aos homens da mesma cor foi em torno de 8,4\%, sendo a maior dentre todos os forros "de cor" (Tabela 3).

No período de 1850 a 1871, os homens pardos continuaram com mais vantagem que as pardas no momento da liberdade. As mulatas continuaram com mais expressão, relativamente ao seu percentual na população cativa, e com relação aos homens (Tabela 4).

No último período analisado, 1871 a 1888, a prerrogativa da alforria ficou para as mulheres pardas. Entre os demais cativos de cor, destacam-se os crioulos, que foram mais beneficiados em relação às mulheres da mesma cor. Entre os cabras a diferença foi pequena, mas a surpresa fica por conta do desempenho das mulheres mulatas, que foi um pouco menor que o dos homens, diferentemente dos períodos anteriores (Tabela 5).

Fica claro que, entre os mestiços, a alforria não pendia exclusivamente para as mulheres, e que os homens estavam disputando de forma acirrada a sua liberdade, ainda que isto não refute a vantagem das mulheres no conjunto dos alforriados. Na primeira metade do século XIX, a representação dos homens na população cativa era de $16 \%$ a mais que as mulheres. Nos dois últimos períodos, esta mesma população tendeu a um equilíbrio entre os sexos (Gráfico 2). A vantagem que as mulheres cativas tiveram em relação aos homens, considerando os três períodos, foi de $16,4 \%, 17,4 \%$ e $13 \%$, respectivamente. Assim, no decorrer do Oitocentos, o desequilíbrio entre os sexos na população cativa foi superado, mas isto não se refletiu no momento da alforria, pois os mecanismos que conduziam à liberdade não se restringiam a uma mera equivalência demográfica.

Um outro ângulo para se observar a preponderância das mulheres no conjunto dos alforriados é comparar o sexo do forro com os tipos de alforrias para mensurar a sua influência.

Ao analisarmos o sexo do alforriado em relação ao tipo de alforria concedida, verificamos que a diferença nas alforrias condicionais, pagas ou não, pendeu para as mulheres, sem grandes disparidades no que se refere aos dois primeiros períodos. Entretanto, no período de 1871-1888, os homens tiveram uma vantagem de $27,2 \%$ sobre as mulheres nas alforrias condicionais e pagas. Esta diferença não foi acompanhada pelas condicionais e não pagas, que permaneceram iguais aos períodos anteriores. A vantagem das mulheres nas alforrias incondicionais e pagas, no período de 1800-1850 e 1850-1871, foi de $17 \%$ e $20 \%$, respectivamente. Já no período de $1871-1888$, esta vantagem caiu para $5,8 \%$. As mulheres foram largamente favorecidas com a alforria gratuita nos três períodos estudados, com os percentuais de $29,2 \%, 35,6 \%$ e 34\%, conforme demonstrado na Tabela 7. 
Tabela 7 - Sexo dos alforriados e tipos da alforria em Rio de Contas (1800-1888)

\begin{tabular}{|c|c|c|c|c|c|c|c|c|c|c|c|}
\hline \multirow{3}{*}{ Períodos } & \multirow{3}{*}{$\begin{array}{c}\text { Sexo do } \\
\text { Alforriado }\end{array}$} & \multicolumn{8}{|c|}{ Tipos de Alforria } & \multirow{2}{*}{\multicolumn{2}{|c|}{ Total }} \\
\hline & & \multicolumn{2}{|c|}{$\begin{array}{c}\text { Paga } \\
\text { incondicional }\end{array}$} & \multicolumn{2}{|c|}{ Gratuita } & \multicolumn{2}{|c|}{$\begin{array}{c}\text { Não paga } \\
\text { condicional }\end{array}$} & \multicolumn{2}{|c|}{$\begin{array}{c}\text { Paga } \\
\text { condicional }\end{array}$} & & \\
\hline & & $\mathrm{N}$ & $\%$ & $\mathrm{~N}$ & $\%$ & $\mathrm{~N}$ & $\%$ & $\mathrm{~N}$ & $\%$ & $\mathrm{~N}$ & $\%$ \\
\hline \multirow{3}{*}{$1800-1850$} & Mulher & 225 & 58,7 & 173 & 64,6 & 130 & 54,2 & 34 & 51,5 & 561 & 58,6 \\
\hline & Homem & 158 & 41,3 & 95 & 35,4 & 110 & 45,8 & 32 & 48,5 & 396 & 41,4 \\
\hline & Total & 383 & 100 & 268 & 100 & 240 & 100 & 66 & 100 & 957 & 100 \\
\hline \multirow{3}{*}{$1850-1871$} & Mulher & 90 & 60,0 & 59 & 67,8 & 84 & 53,2 & 13 & 54,2 & 246 & 58,7 \\
\hline & Homem & 60 & 40,0 & 28 & 32,2 & 74 & 46,8 & 11 & 45,8 & 173 & 41,3 \\
\hline & Total & 150 & 100 & 87 & 100 & 158 & 100 & 24 & 100 & 419 & 100 \\
\hline \multirow{3}{*}{$1871-1888$} & Mulher & 63 & 52,9 & 73 & 67,0 & 85 & 53,5 & 4 & 36,4 & 225 & 56,5 \\
\hline & Homem & 56 & 47,1 & 36 & 33,0 & 74 & 46,5 & 7 & 63,6 & 173 & 43,5 \\
\hline & Total & 119 & 100 & 109 & 100 & 159 & 100 & 11 & 100 & 398 & 100 \\
\hline
\end{tabular}

Fonte: AMRC, Livros de Notas do Tabelionato, 1800-1888.

A historiografia brasileira apresenta algumas hipóteses sobre a vantagem das mulheres no momento da alforria. Entre elas, a de o valor de mercado da mulher cativa ser inferior ao do homem em função da sua resistência física e produtividade. ${ }^{69}$ Em Rio de Contas, os preços oscilaram durante todo o século XIX, mas, somente na década de 1830 , o preço da alforria pago pelas mulheres foi cerca de $20 \%$ maior que o preço pago pelos homens. ${ }^{70}$ Apesar de os índices de alforrias masculinas terem aumentado nesta década, as mulheres continuaram conquistando-as sem que houvesse declínio significativo a favor dos homens. Nas demais décadas, os preços dos escravos foram, em média, maiores do que o das escravas, sendo mais significativos nos decênios de 1840 e 1860. A despeito disso, as diferenças não foram tão expressivas, à exceção das décadas salientadas, talvez pelo fato de as pequenas lavouras não exigirem grande força física, empregando cativos de ambos os sexos. Não havendo uma grande disparidade de preços por sexo, e por outro lado, não sendo a alforria negociada exclusivamente por um preço de mercado, mas também pelo tipo de relação que o cativo mantinha com seus senhores, ou seja, pelo "grau de intimidade de que o cativo goza junto a seu senhor, de sentimentos difíceis de serem contabilizados, nos quais influenciam os matizes da amizade ou da indiferença", não acreditamos que o mercado tenha sido causa causans na vantagem das mulheres. ${ }^{71}$

Se levarmos em consideração que parte considerável das alforrias foi adquirida mediante a indenização do valor do escravo, podemos levantar a hipótese de que a ocupação exercida pelas cativas na região tivesse possibilitado um acúmulo significativo de pecúlio. Mas, como já dissemos, dados sobre a ocupação do escravo nas cartas de alforria são raros. No caso dos inventários, verificamos um equilíbrio entre as cativas de origem africana e afro-brasileira que se dedicavam aos serviços de roça, porém, nos serviços de casa, a preferência era pelas nascidas no Brasil. Portanto, a proximidade da família senhorial estaria favorecendo estas cativas. Não era raro as escravas se ocuparem dos serviços de casa e de outra atividade, como rendeiras, costureira ou fiandeira. ${ }^{72}$ Quiçá elas vendessem o produto do seu trabalho fora da morada do senhor, o que lhes possibilitava o acúmulo de um pecúlio.

A Tabela 7 mostra que, nos dois primeiros períodos analisados, o pagamento foi um recurso de grande importância na aquisição da alforria pela mulher escrava. Ainda nestes dois períodos, a análise do tipo de pagamento revela que, das 272 cartas pagas pelo próprio escravo, 56,3\% foram adquiridas por mulheres, fato que confirma que as cativas tinham mais possibilidade de formar um pecúlio para a 
aquisição de suas alforrias. Este foi, por exemplo, o caso de Ignes, preta, de 45 anos aproximadamente, que comprou sua alforria por $146 \$ 000$ mil-réis, e ficou prestando serviços de bater "taxos em moagem a limpas de açúcar" por dois anos. Atividade análoga é até hoje exercida pelas mulheres da região. O dinheiro acumulado por Ignes, fruto do seu ofício, proporcionou-lhe a compra da liberdade..$^{73}$

Alguns relatos nas cartas de liberdade deixam entrever as redes de solidariedade da família escrava em prol da alforria. Em 1801, Clara da Rocha comprou a alforria de sua filha Luzia e de sua neta Verônica, pagando parte à vista, restando uma dívida. Em 1807, as alforrias foram registradas em cartório, e inferimos que, naquela ocasião, Clara conseguira quitar o débito com Antônio da Silva Lino. Como Clara acumulou o dinheiro para tanto é uma resposta que não temos, mas deduzimos que era forra em razão do tratamento respeitoso de senhora a ela atribuído no documento. ${ }^{74}$ Importa salientar que a família aumentava as possibilidades de alforria, como já foi constatado por outros estudiosos do tema. ${ }^{75}$

Do relato acima, podemos também conjecturar que, por a mulher perpetuar a condição escrava com o seu ventre, ela fosse preferida pela sua família no momento da alforria. No conjunto das cartas em que o pagamento foi feito por familiares, as mulheres foram largamente beneficiadas, à razão de $82,9 \%$, ou seja, foi contando com a solidariedade dos seus parentes que cativas como Luzia e Verônica conseguiram conquistar a liberdade.

Outra hipótese é a de a mulher, sobretudo a brasileira, contar com maiores possibilidades de estabelecer relacionamentos com suas senhoras e senhores, que facilitaram a obtenção de alforrias. Esses laços poderiam decorrer tanto das ocupações por elas exercidas como domésticas, amas de leite e mucamas, quanto de relações sexuais mantidas com os senhores. As alforrias tendiam a beneficiar mais as cativas que conviviam diariamente com a família senhorial, em detrimento daquelas que trabalhavam na roça. Os textos das cartas de alforria contam-nos histórias de senhoras e senhores gratos pelo fato de suas escravas terem criado ou amamentado seus filhos, de serem suas crias, de terem-lhes dado crias, ou ainda dos cuidados a eles dispensados durante alguma enfermidade. ${ }^{76}$

Uma das justificativas para alforriar era o escravo ser cria da casa, e os senhores terem estima por ele. Algumas crianças foram alforriadas por seus padrinhos ou madrinhas, e algumas cartas de alforria foram também cartas de reconhecimento da paternidade. ${ }^{77}$ Enfim, os bons serviços e as relações afetivas e de parentesco constituíram elementos importantes para o predomínio das mulheres (e de crianças) no conjunto dos escravos alforriados como ficou demonstrado no desempenho que tiveram nas alforrias gratuitas, com mais de $65 \%$, considerado todo o período analisado. Entretanto, o fato de uma escrava ter uma relação tão próxima com seus senhores pressupunha obediência irrestrita às suas vontades, pois qualquer indisciplina quebrava a frágil estabilidade em que vivia. A historiografia tem demonstrando o quanto os senhores podiam ser cruéis com seus cativos, vendendo-os ou castigando-os. ${ }^{78}$

Outra hipótese levantada pela historiografia é de que a condição submissa da mulher numa sociedade patriarcal contribuiu para que fosse preferida no momento da alforria. Assim, da perspectiva dos senhores, o grande número de mulheres libertas, por sua própria condição subalterna, não significaria um perigo à ordem estabelecida, ao contrário dos libertos. ${ }^{79}$ Esta é uma hipótese bastante plausível, pois se compararmos o sexo com o tipo de alforria (Tabela 7), verificamos que a vantagem da mulher não era a mesma em todos os tipos, e nem em todos os períodos. Nas pagas e incondicionais, por exemplo, a diferença foi significativa até a Lei do Ventre Livre, que abriu maiores possibilidades de alforria a todos os cativos, e isto se refletiu no crescimento das manumissóes pagas pelos homens. Nas alforrias condicionais pagas e não pagas, a frequência das mulheres foi apenas um pouco maior que a dos homens, sendo que, no último período, os homens tiveram vantagem de $27,2 \%$ nas condicionais e pagas. Neste tipo de alforria o domínio senhorial continuava presente, pois o liberto só poderia usufruir da liberdade mediante o cumprimento de alguma condição, que era pré-requisito para aquela se concretizar.

E, por último, consideramos a influência do sexo do proprietário em alforriar seus escravos. Do conjunto das 1.777 alforrias analisadas, $1.181(66,5 \%)$ foram concedidas por proprietários, enquanto 
que as proprietárias foram responsáveis por $595(33,5 \%)$ das cartas de alforrias. ${ }^{80}$ Neste universo, não houve uma correspondência entre o sexo do proprietário e o do alforriado, em outras palavras, tanto mulheres quanto homens alforriaram mais as mulheres cativas. Vale lembrar que a propriedade em escravos foi mais expressiva entre os homens do que entre as mulheres no município de Rio de Contas.

Assim, a maior presença das mulheres na obtenção da alforria deve-se a um conjunto de fatores, não cabendo uma explicação única. As diversas estratégias que as mulheres adotaram, ou que foram adotadas em seu favor, parecem ter possibilitado que elas amealhassem mais resultados que os homens.

\section{Considerações finais}

Enfim, vimos que a população escrava em Rio de Contas era composta fundamentalmente por cativos nascidos no Brasil. Esta crioulização demográfica, ocorrida já antes do fim do tráfico transatlântico de escravos em 1850, promoveu um maior equilíbrio entre os sexos na população cativa. Assim, a análise da composição dos cativos em Rio de Contas possibilitou traçar um perfil da população cativa em risco de ser alforriada, ou seja, os cativos nascidos no Brasil, especificamente crioulos e cabras.

A partir da análise das variáveis origem, cor, nação e sexo nas cartas de alforria foi possível mensurar o desempenho diferenciado dos nascidos no Brasil e dos escravos africanos na conquista da liberdade. Ficou evidenciado que, em todo o período analisado, os escravos nascidos no Brasil foram mais favorecidos no momento da alforria, comparativamente aos cativos de origem africana. No entanto, a cor também representou uma barreira na conquista da liberdade e, dentre os nascidos no Brasil, verificamos que os miscigenados se saíram melhor, sobretudo nos dois primeiros períodos estudados. Já no último período, 1871-1888, foram os crioulos e cabras que obtiveram mais êxito. Assim, no quesito cor não houve correspondência demográfica entre cativos e forros em Rio de Contas. No tocante à nação dos cativos de origem africana que conquistaram a alforria, vimos que minas e angolas se sobressaíram, havendo uma relativa correspondência demográfica se comparada ao que representavam na população cativa. Constatamos ainda o predomínio do registro de alforrias de mulheres, o que confirma a tendência detectada para outras regiôes do Brasil. Contudo, estas conclusões foram matizadas quando comparamos esta variável com a cor do alforriado: os homens miscigenados estavam disputando e levando vantagem, em alguns casos, sobre as mulheres miscigenadas. Dessa forma, os homens mestiços lutaram pela liberdade com empenho igual às mulheres, superando-as em algumas categorias de cor.

\section{Notas}

${ }^{1}$ Este artigo é uma versão modificada do terceiro capítulo da Dissertação de Mestrado "Alforrias em Rio de Contas, Bahia, Século XIX” (Dissertação de Mestrado, Programa de Pós-graduação em História Social da Universidade Federal da Bahia, 2006), sob a orientação do Prof. Dr. João José Reis.

${ }^{2}$ Erivaldo Fagundes Neves e Antonieta Miguel (orgs.), Caminhos do Sertão: ocupação territorial, sistema viário e intercâmbios coloniais dos Sertôes da Bahia, Salvador, Arcádia, 2007, p. 25-32.

${ }^{3}$ Albertina Vasconcelos, Ouro: conquistas, tensões, poder, mineração e escravidão - Bahia do século XVIII (Dissertação de Mestrado, Unicamp, 1998).

${ }^{4}$ Almeida, "Alforrias em Rio de Contas", p. 23-31.

${ }^{5}$ Joahnn B. Spix e Carl F. P. von Martius, Viagem pelo Brasil, 1817-1820, Belo Horizonte/ São Paulo, Itatiaia/Edusp, 1981, v. II, p. 128; Kátia Mattoso, Bahia: a Cidade do Salvador e seu mercado no século XIX, São Paulo, Hucitec, 1978, p. 127-133.

${ }^{6}$ Sobre o período pré-censitário do Brasil, ver Flavio Rabelo Versiani, Ronaldo Serôa Motta e Wilson Suzigan (Orgs.), Estatísticas Históricas do Brasil: séries econômicas, demográficas e sociais de 1550 a 1988, Rio de Janeiro, IBGE, 1990.

${ }^{7}$ Sobre a composição da população cativa em Salvador ver Maria José de Souza Andrade, A mão de obra escrava em Salvador, 1811-1860, São Paulo/Brasília, Corrupio/CNPq, 1988, p. 114-120; João José Reis, Rebelião Escrava no Brasil: a história do levante dos malês em 1835, São Paulo, Companhia das Letras, 2003, p. 20-27; para o Recôncavo baiano ver Bert Barickman, Um contraponto baiano: açúcar, fumo, mandioca e escravidão no Recôncavo, 1780-1860, Rio de Janeiro, Civilização Brasileira, 2003, p. 211-266. 
${ }^{8}$ A estimativa tem como base o Livro de Matrícula de Escravos 1748-1749 de Minas do Rio de Contas, cf. Vasconcelos, "Ouro: conquistas, tensōes, poder, mineração e escravidão", p. 271-273. Stuart Schwartz informa-nos que, "entre 1778 e 1798, foram mandados de Salvador para o sertão 2844 escravos: 634 minas, 47 nagôs e jejes e 2163 angolas, benguelas e congos”. Contudo, não fica claro qual o percentual destes escravos que foram para o Alto Sertão da Bahia, especificamente para o município de Rio de Contas. Ver Stuart B. Schwartz, Segredos Internos: engenhos e escravos na sociedade colonial, 15501835, São Paulo, Companhia das Letras, 1988, p. 284.

${ }^{9}$ Barickman, Um contraponto baiano, p. 252-254.

${ }^{10}$ Vasconcelos, "Ouro: conquistas", p. 271. Sobre a demografia escrava em Salvador ver, Reis, Rebeliāo Escrava, p. 20-27 e Andrade, A mão de obra escrava, p. 27-126; para o Recôncavo baiano ver Schwartz, Segredos internos, p. 286-291; Barickman, Um contraponto baiano, p. 213-266; para a região mineradora de Minas Gerais cf. Douglas Cole Libby, Transformação e Trabalho em uma economia escravista: Minas Gerais no século XIX, São Paulo, Brasiliense, 1988, p. 56-63; Carla Maria Carvalho de Almeida, "A população escrava em Minas Gerais", in: Revista Eletrônica História do Brasil, v. 3, n. 1 (1999), p. 38-53.

${ }^{11}$ Barickman, Um contraponto baiano, p. 252-264.

${ }^{12}$ Cf. Almeida, "Alforrias em Rio de Contas", p. 170.

${ }^{13}$ Andrade, A mão de obra escrava, p. 114-120; Reis, Rebeliāo Escrava, p. 19-43 e p. 307-349.

${ }^{14}$ Pesquisamos uma amostra de 300 inventários post mortem entre 1800 a 1888, cujos senhores possuíam escravos.

${ }^{15}$ Luis Nicolau Parés, “O processo de crioulização no Recôncavo baiano (1750-1800)”, Afro-Ásia, no 33 (2005), p. 87-132 (p. 88 para o trecho citado). Neste artigo o autor discute a crioulização na perspectiva cultural e demográfica. O aspecto relevante para este estudo é o demográfico.

${ }^{16}$ Não pretendo neste trabalho discutir a formação e a manutenção da família escrava em Rio de Contas, assunto para outro artigo, mas tão somente apontar a sua importância no processo de crioulização demográfica da população escrava na primeira metade do século XIX. Sobre a família no contexto de tráfico aberto intenso, que não é o caso de Rio de Contas, ver Manolo Florentino e Cacilda Machado, "Família e mercado: tipologias parentais de acordo ao grau de afastamento do mercado de cativos (século XIX)”, Afro-Ásia, no 24 (2000) p. 51-70.

${ }^{17}$ Arquivo Público do Estado da Bahia (APEB doravante), Seção Arquivos Colônias e Provinciais, Série Justiça, Correspondências recebidas de Juízes, Minas do Rio de Contas, maços 2483, 1827-1859 e 2559, 1847-1851. Vale lembrar que não foram localizados livros de registros de casamentos para as freguesias que compunham o município de Rio de Contas no século XIX.

${ }^{18}$ APEB, Seção Arquivos Colônias e Provinciais, Série Justiça, Correspondências recebidas de Juízes, Minas do Rio de Contas, maços 2483, 1827-1859 e 2559, 1847-1851.

${ }^{19}$ Barikcman, Um contraponto baiano, p. 259.

${ }^{20}$ Barikcman, Um contraponto baiano, p. 259. Para efetuar a estimativa, o autor considerou as crianças com até 10 anos de idade. Calculamos a estimativa da taxa de sobrevivência dos filhos das escravas com base em Barickman p. 259, nota 65 e consiste em: multiplicar a razão criança/mulher por 30 (período de idade reprodutiva) e dividir o produto por 5 (metodologia IBGE) ou 10 (metodologia usada por Barickman). A opção em dividir por 5 foi por entender-se que até cinco anos a criança tem o sistema imunológico mais frágil e, até esta faixa etária, a mortalidade é maior.

${ }^{21}$ Schwartz, Segredos internos, p. 291-299; Barickman, Um contraponto baiano, p. 258-261.

${ }^{22}$ Barickman, Um contraponto baiano, p. 259.

${ }^{23}$ Mary Ann Mahony, “'Instrumentos necessários' escravidão e posse de escravos no sul da Bahia no século XIX, $1822-$ 1889”, Afro-Ásia, no 25/26 (2001) p. 95-139. Sobre a morte como uma forma de libertação do cativeiro cf. Isabel Cristina Ferreira dos Reis, História de vida familiar e afetiva de escravos na Bahia do século XIX, Salvador, CEB, 2001, p. 111-115. Casos de infanticídio e abortos praticados por escravas no Alto Sertão, cf. Maria de Fátima Novaes Pires, O crime na cor: escravos e forros no Alto Sertão da Bahia (1830-1888), São Paulo, Annablume/Fapesp, 2003, p. 178-182.

${ }^{24}$ Barickman, Um contraponto baiano, p. 89-96, 263-264 e cap. 6; Parés, “O processo de crioulização”, p. 105.

${ }^{25}$ A fazenda Brejo do Campo Seco localizava-se em Bom Jesus dos Meira (Brumado) que até a emancipação de Caetité, em 1810, pertenceu a Rio de Contas. Ver Licurgo Santos Filho, Uma comunidade rural do Brasil antigo: aspectos da vida patriarcal no sertão da Bahia nos séculos XVIII e XIX, São Paulo, Cia. Editora Nacional, 1956, p. 313, 320-322.

${ }^{26}$ Lorand Matory, “Jeje: repensando naçōes e transnacionalismo”, Mana 5 (1999), p. 60.

${ }^{27}$ Maria Inês Côrtes de Oliveira, "Quem eram os 'negros da Guiné’? A origem dos africanos na Bahia”, Afro-Ásia, 19/20 (1997) p. 37-73; Frederik Barth, "Grupos étnicos e suas fronteiras”, in Philippe Poutgnat e Jocelyne Streiff-Fenart (orgs.), Teorias da Enticidade (São Paulo, UNESP, 1997) p. 187-222; Luis Nicolau Parés, A formação do candomblé: história e ritual da nação jeje na Bahia, Campinas, Ed. Unicamp, 2006.

${ }^{28}$ Para Soares, os nomes das procedências atribuídas aos africanos não apresentam nenhuma homogeneidade: "vão desde os nomes de ilhas, portos de embarque, vilas e reinos a pequenos grupos étnicos". Cf. Mariza de Carvalho Soares, Devotos da Cor: identidade étnica, religiosidade e escravidão no Rio de Janeiro, século XVIII, Rio de Janeiro, Civilização Brasileira, 2000 , p. 109. 
${ }^{29}$ Oliveira, "Quem eram os "negros da Guiné”?", p. 47-56; Maria Inês Cortês de Oliveira, "Viver e Morrer no meio dos seus: nações e comunidades africanas na Bahia do século XIX”, Revista da USP, no 28 (1995/1996) p. 174-196; Parés, A formação do candomblé, p. 23-29. Para o Rio de Janeiro, ver Soares, Devotos da Cor, p. 95-127.

${ }^{30}$ Oliveira, "Viver e Morrer", p. 175; Reis, Rebelião Escrava, p. 333-349; Parés, A formação do candomblé, p. 30-62.

${ }^{31}$ Oliveira, “Quem eram os 'Negros da Guiné?” p. 58-63 (p. 58 para o trecho citado).

32 Reis, Rebeliāo Escrava no Brasil, p. 328.

${ }^{33}$ A expressão "guarda-chuva" foi usada por João José Reis para designar "a incorporação de membros de etnias menores às redes de grupos majoritários". Cf. Rebelião Escrava no Brasil, p. 339 e "A Greve Negra de 1857 na Bahia”, Revista USP, nº 18 (1993) p. 28-29.

${ }^{34}$ Andrade, $A$ mão de obra escrava, p. 104.

${ }^{35}$ Andrade, $A$ mão de obra escrava, p. 104.

${ }^{36}$ Sobre os angolas no Rio de Janeiro ver Mary C. Karasch, A vida dos escravos no Rio de Janeiro (1808-1850), São Paulo, Companhia das Letras, 2000, p. 55-58.

${ }^{37}$ Ressaltamos que as denominações apresentadas na Tabela 1, para os cativos nascidos no Brasil, foram aquelas extraídas da documentação.

38 Soares, Devotos da Cor, p. 96.

${ }^{39}$ Antonio de Moraes Silva, Dicionário da Língua Portuguesa, Lisboa, Tipografia Lacerdina, 1813, 2 v., vol. 1 p. 314, 496; vol. 2 p. 294, 327, 398.

${ }^{40}$ Preto, a partir da Lei do Ventre Livre, parece indicar tanto o negro africano quanto o nascido no Brasil. Ver a respeito João José Reis, "De olho no canto: trabalho de rua na Bahia na véspera da abolição", Afro-Ásia, no 24 (2000), p. 232-234; Reis, Rebeliāo Escrava, p. 23; sobre as classificações raciais ver Jocélio Teles dos Santos, "De pardos disfarçados a brancos pouco claros: classificaçōes raciais no Brasil dos séculos XVIII-XIX”, Afro-Ásia, no 32 (2004), p. 115-137.

${ }^{41}$ Hebe Maria Mattos, Das cores do silêncio: os significados da liberdade no Sudoeste escravista, Brasil Século XIX, Rio de Janeiro, Nova Fronteira, 1998, p. 98-99.

${ }^{42}$ Spix e Martius, Viagem pelo Brasil, p. 129, 149 e 164.

${ }^{43}$ Arquivo Municipal de Rio de Contas (doravante AMRC), Seção Judiciário, Livro de Notas do Tabelião, nº 39, fl. 206 v e $207(10 / 05 / 1843)$.

${ }^{44}$ Reis, "De olho no canto", p. 233.

${ }^{45}$ Andréa Lisly Gonçalves, "Alforrias na Comarca de Ouro Preto (1808-1870)”, População e Família, no.3 (2000), p. $165-166$.

${ }^{46}$ Kátia de Queiroz Mattoso, “A propósito de cartas de alforria, Bahia 1779-1850”, Anais de História, no. 4 (1972), p. $37-$ 38 e 40-42 (p. 37 para o trecho citado; ver especialmente tabela II à p. 38). Para uma melhor aproximação com o período por nós estudado, consideramos os dados de Mattoso de 1805 a 1850.

${ }^{47}$ Mieko Nishida. "As alforrias e o papel da etnia na escravidão urbana: Salvador, Brasil, 1808-1888”, Estudos econômicos, vol. 23, no 2 (1993), p. 241-242.

${ }^{48}$ Ver Reis, Rebelião Escrava, p. 19-43 e p. 307-349; Andrade, A mão de obra escrava, p. 27-126.

${ }^{49}$ AMRC, Seção Judiciário, Livro de Notas do Tabeliāo, no 33, fls. 79 e 79 v. (16 /06/1826).

${ }^{50}$ Manolo Florentino, "Sobre minas, crioulos e a liberdade costumeira no Rio de Janeiro, 1789-1871", in Manolo Florentino (org.), Tráfico, Cativeiro e Liberdade (Rio de Janeiro, Civilização Brasileira, 2005), p. 350-355.

${ }^{51}$ Sheila de Castro Faria, "Aspectos demográficos da alforria no Rio de Janeiro e em São João Del Rey entre 1700 e 1850 ”, in: XVI Encontro Nacional de Estudos Populacionais As Desigualdades Sócio-Demográficas e os Direitos Humanos no Brasil, Disponível em <www.abep.nepo.unicamp.br/encontro2008/.../ABEP2008_1431.pdf.> Acesso em: 20/06/2009.

${ }^{52}$ Mattoso, “A propósito", ver especialmente a tabela no 3 à pagina 39.

${ }^{53}$ Nishida, "As alforrias", p. 245-246.

${ }^{54}$ Para o período entre 1850 a 1871 encontramos 33 alforriados com indicação de serem naturais da África e desses apenas 4 com identificação da nação - três nagôs e um benguela. Para o período entre 1871 a 1888 não há informação de nação para nenhum dos 22 alforriados naturais da África.

${ }_{55}$ Nishida, "As alforrias", p. 246.

${ }^{56}$ AMRC, Livro de Notas do Tabeliāo, no 34, fls. 91 v. e 92 e fls. 122 (11/01/1830 e 17/08/1830).

${ }^{57}$ Para 73,7\% dos cativos não havia informação sobre a idade neste período.

${ }^{58}$ Katheleen Higgings, Licencious Libert in a Brazilian Gold-Mining Region, University Park, Pensylvania State University Press, 1999, p. 219-220.

${ }^{59}$ Em Nishida Tabelas 2 e 4, ver Nishida, “As alforrias”, p. 234 e 237. 
${ }^{60}$ Peter L. Eisenberg, "Ficando Livre: As alforrias em Campinas no Século XIX”, Estudos Econômicos, vol. 12, no 2 (1987), p. 186-188; Higgins, Licentious Liberty, cap. 5 e passim.

${ }^{61}$ Nishida, "As alforrias", p. 237 e 243 (tabelas 2 e 4). Como as tabelas foram construídas considerando os períodos de 1808 a 1842 e 1852-1888, fica prejudicada a análise mais específica para o período após a Lei do Ventre Livre.

${ }^{62}$ Cf. Censo Demográfico de 1872, in Manoel Jesuíno Ferreira, A Província da Bahia: apontamentos, Rio de Janeiro, Typ. Nacional, 1875, p. 36-37.

${ }^{63}$ Para uma análise dos tipos de alforria e as transformaçōes ocorridas na prática de alforriar, considerando os períodos de 1800-1850; 1850-1871; 1871-1888, em Rio de Contas, cf. Kátia Lorena Novais Almeida, "Da prática costumeira à alforria legal”, Politeia, v. 7, no 1 (2007), p. 163-186.

${ }^{64}$ AMRC, Seção Judiciário, Livro de Notas do Tabeliāo, no 31, fl. 88 (08/09/1817).

${ }^{65}$ Sobre o aumento da alforrias condicionais após 1850 em Rio de Contas, ver Almeida, "Alforrias em Rio de Contas", p. 58-59. Sobre a alforria enquanto "contrato de trabalho" nas últimas décadas da escravidão, ver Eisenberg, "Ficando Livre", p. 196-209. Lima levantou para Desterro 56 "contratos de locação de serviços” para pagamento da alforria, ver Henrique Espada Lima, Sob o domínio da precariedade: escravidão e os significados da liberdade de trabalho no século XIX. Topoi.v. 6, nº 11. Rio de Janeiro: UFRJ/ 7Letras, 2005, p. 289-326.

${ }^{66}$ Andréa Lisly Gonçalves, "As margens da liberdade: estudo sobre a prática de alforrias em Minas colonial e provincial”, (Tese de Doutorado, USP, 1999), p. 237-239.

${ }^{67}$ Kátia de Queirós Mattoso, Ser Escravo no Brasil, São Paulo, Brasiliense, 2003, p. 185. Na Tabela IV do artigo "A propósito das cartas de alforria" Mattoso constatou que foi expressivo o número de mulheres alforriadas em Salvador. Para efeito de comparação com o nosso trabalho, consideramos os dados por ela apurados para o período de 1805 a 1850 , cuja proporção foi de 158 mulheres para 100 homens. Cf. Mattoso, "A propósito", p. 40-41.

${ }^{68} \mathrm{~A}$ análise da Tabela 5 do artigo de Nihida informa as razões entre homens e mulheres forros. No período de 1808-1842 a proporção por sexo foi de 136 mulheres para 100 homens. Os dados apresentados nesta tabela permitem-nos concluir que em alguns anos da amostra por ela estudada houve grandes disparidades (1851-52 a proporção de 178 mulheres alforriadas para 100 homens), e em outras não (1831-32 a proporção foi de 108 mulheres para 100 homens). Ver Nishida, "As alforrias", p. 241-245.

${ }^{69}$ Mattoso, "A propósito", p. 40; Eisenberg, "Ficando Livre”, p. 182.

${ }^{70}$ Cf. Almeida, "Alforrias em Rio de Contas", p. 169.

${ }^{71}$ Elementos como idade, ocupação e origem influenciavam no preço dos escravos. Ver Kátia M. de Queirós Mattoso, Herbert S. Klein e Stanley L. Engerman, "Notas sobre as tendências e padrōes dos preços de alforrias na Bahia, 1819-1888”, in João José Reis (org.) Escravidão e Invenção da Liberdade: Estudos sobre o negro no Brasil (São Paulo, Brasiliense, 1988), p. 60-72; Kátia M de Queirós Mattoso, Ser Escravo no Brasil, São Paulo, Brasiliense, 2003, p. 182-184 (p.183 para o trecho citado).

${ }^{72}$ Sobre as ocupaçôes exercidas pelas cativas no município de Rio de Contas, cf. Almeida, "Alforrias em Rio de Contas", p. 35.

${ }^{73}$ AMRC, Seção Judiciário, Livro de Notas do Tabelião, no 52, fl. 55 ( 21/01/1887).

${ }^{74}$ AMRC, Seção Judiciário, Livro de Notas do Tabeliāo, no 23, fl. 05 (11/10/1801 e 14/03/1807).

${ }^{75}$ Cf. Eisenberg, "Ficando Livre", p. 182-184; Eduardo França Paiva, Escravos e libertos nas Minas Gerais do Século XVIII: estratégia de resistência através dos testamentos, São Paulo, Anablume, 1995, p. 119-128; Regina Célia Lima Xavier, A Conquista da Liberdade. Libertos em Campinas na segunda metade do século XIX, Campinas, Centro de Memória da Unicamp, 1996, p. 41; Isabel Cristina Ferreira dos Reis, Histórias de vida familiar e afetiva de escravos na Bahia do século XIX, Salvador, Centro de Estudos Baianos, 2001, p. 120-124.

${ }^{76}$ Eisenberg, "Ficando Livre", p. 182.

${ }^{77}$ Cf. Almeida, "Alforrias em Rio de Contas”, capítulo 4.

${ }^{78}$ Para uma análise das ambiguidades da relação senhor/escravo ver Ligia Bellini, "Por amor e por interesse: a relação senhor-escravo em cartas de alforria”, in João José Reis (org.) Escravidão e Invenção da Liberdade: estudos sobre o negro no Brasil (São Paulo, Brasiliense, 1988), p. 73-86; Silvia Hunold Lara, Campos da violência: escravos e senhores na capitania do Rio de Janeiro, 1750-1808, Rio de Janpeiro, Paz e Terra, 1988; Maria de Fátima Novaes Pires, O crime na cor: escravos e forros no Alto Sertão da Bahia (1830-1888), São Paulo, Annablume/Fapesp, 2003.

${ }^{79}$ Ver Marcus J. M. de Carvalho, Liberdade: rotinas e rupturas do escravismo no Recife, 1822-1850, Recife, Ed. Universitária da UFPE, 2002, p. 224-225.

${ }^{80}$ Exclui-se uma carta em que não foi possível verificar o sexo do proprietário (a), pois o documento estava danificado. 


\section{Referências bibliográficas}

AGUIAR, Durval Vieira de. Descriçôes práticas da Provincia da Bahia com declaraçôes de todas as distancias intermediárias das cidades, vilas e povoaçôes. Rio de Janeiro/Brasília: Cátedra/INL, 1979.

ALMEIDA, Carla Maria Carvalho de. A população escrava em Minas Gerais. Revista Eletrônica História do Brasil, v. 3, no 1, p. 38-53, 1999.

ALMEIDA, Kátia Lorena Novais. Alforrias em Rio de Contas, Bahia - Século XIX. Dissertação de Mestrado apresentada ao Programa de Pós-graduação em História da UFBA. Salvador, 2006.

Da prática costumeira à alforria legal. Politeia, v. 7, no 1, p. 163-186, 2007.

ANDRADE, Maria José de Souza. A mão de obra escrava em Salvador, 1811-1860. São Paulo: Corrupio, 1988.

ATAÍDE, Gonçalo Pereira de. Minas do Rio de Contas, hoje município do Rio de Contas. Bahia: Tip. São Miguel, 1940.

BARICKMAN, Bert J. As cores do escravismo: escravistas "pretos", "pardos" e "cabras" no Recôncavo Baiano, 1835. População e Família, no 2, p. 7-59, 1999.

BARTH, Frederik. Grupos étnicos e suas fronteiras. In: POUTGNAT, Philippe e STREIFF-FENART, Jocelyne (Orgs.). Teorias da etnicidade. São Paulo: UNESP, 1997, p. 187-222.

BELLINI, Ligia. Por amor e por interesse: a relação senhor-escravo em cartas de alforria. In: REIS, João José (Org.). Escravidão e invenção da liberdade: estudos sobre o negro no Brasil. São Paulo: Brasiliense, 1988, p. 73-86.

CARVALHO, Marcus J. M. de. Liberdade: rotinas e rupturas do escravismo no Recife, 1822-1850. Recife: Ed. UFPE, 2002.

EISENBERG, Peter L. Ficando Livre: As alforrias em Campinas no Século XIX. Estudos Econômicos, vol.12, no 2, p. 175-216, 1987.

FARIA, Sheila de Castro. Aspectos demográficos da alforria no Rio de Janeiro e em São João Del Rey entre 1700 e 1850. In: XVI Encontro Nacional de Estudos Populacionais as Desigualdades Sóciodemográficas e os Direitos Humanos no Brasil. Disponível em <www.abep.nepo.unicamp.br/encontro2008/.../ABEP2008_1431.pdf.> Acesso em: 20/06/2009.

FLORENTINO, Manolo. Sobre minas, crioulos e a liberdade costumeira no Rio de Janeiro, 1789-1871. In: FLORENTINO, Manolo (Org.). Tráfico, cativeiro e liberdade. Rio de Janeiro: Civilização Brasileira, 2005, p. 350-355.

GOMES, Josildete. Povoamento da Chapada Diamantina. Revista IGHB, no 77, p. 221-238, 1952.

GONÇALVES, Andréa Lisly. As margens da liberdade: estudo sobre a prática de alforrias em Minas colonial e provincial. Tese de doutorado apresentada ao Programa de Pós-graduação em História da USP. São Paulo, 1999.

. Alforrias na Comarca de Ouro Preto (1808-1870). População e Família, no 3, p. 157-180, 2000.

HIGGINGS, Katheleen. Licencious libert in a Brazilian gold-mining region. University Park: Pensylvania State University Press, 1999.

KARASCH, Mary C. A vida dos escravos no Rio de Janeiro (1808-1850). São Paulo: Companhia das Letras, 2000.

LARA, Silvia Hunold. Campos da violência: escravos e senhores na capitania do Rio de Janeiro, 1750-1808. Rio de Janeiro: Paz e Terra, 1988.

LIBBY, Douglas Cole. Transformação e trabalho em uma economia escravista: Minas Gerais no século XIX. São Paulo: Brasiliense, 1988.

LIMA, Henrique Espada. Sob o domínio da precariedade: escravidão e os significados da liberdade de trabalho no século XIX. Topoi, v. 6, no 11. Rio de Janeiro: UFRJ/ 7Letras, p. 289-326, 2005.

MAHONY, Mary Ann. "Instrumentos necessários". Escravidão e posse de escravos no sul da Bahia no século XIX, 1822-1889. Afro-Ásia, no 25/26, p. 95-139, 2001.

MATORY, Lorand. Jeje: repensando nações e transnacionalismo. Mana, no 5, p. 57-71, 1999.

MATTOS, Hebe Maria. Das cores do silêncio: os significados da liberdade no Sudoeste escravista, Brasil Século XIX. Rio de Janeiro: Nova Fronteira, 1998.

MATTOSO, Kátia M. de Q. A propósito de cartas de alforria, Bahia 1779-1850. Anais de História, no 4, p. 2352, 1972. 
. Bahia: a cidade do Salvador e seu mercado no século XIX. São Paulo/Salvador: Hucitec/Secretaria Municipal de Educação e Cultura, 1978.

Ser escravo no Brasil. São Paulo: Brasiliense, 2003.

MATTOSO, Kátia M de Queirós; KLEIN, Herbert S.; ENGERMAN, Stanley L. Notas sobre as tendências e padrōes dos preços de alforrias na Bahia, 1819-1888. In: REIS, João José (Org.) Escravidão e invenção da liberdade: estudos sobre o negro no Brasil. São Paulo, Brasiliense, 1988, p. 60-72.

NEVES, Erivaldo. Uma comunidade sertaneja: da sesmaria ao minifúndio (um estudo de historia regional e local). Salvador/Feira de Santana: Edufba/Eduefs, 1998.

. Almocafres, bateias, e gente da pequena esfera: o ouro no povoamento e ocupação econômica dos sertôes da Bahia. Revista do IGHB, v. 101, p. 125-147, 2006.

Sampuleiros e traficantes: comércio de escravos do Alto Sertão da Bahia para o oeste cafeeiro paulista. Afro-Ásia, no 24, p. 97-128, 2000.

NEVES, Erivaldo F. e MIGUEL, Antonieta (Orgs.). Caminhos do sertão: ocupação territorial, sistema viário e intercâmbios colônias dos sertôes da Babia. Salvador: Ed. Arcádia, 2007.

NISHIDA, Mieko. As alforrias e o papel da etnia na escravidão urbana: Salvador, Brasil, 1808-1888. Estudos econômicos, v. 23, no 2, p. 227-265, 1993.

OLIVEIRA, Maria Inês Côrtes de. Viver e morrer no meio dos seus: naçôes e comunidades africanas na Bahia do século XIX. Revista da USP, no 28, p. 175-193 1995/1996.

Quem eram os 'negros da Guiné'? A origem dos africanos na Bahia. Afro-Ásia, no 19/20, p. 37-73, 1997.

PARÉS, Luis Nicolau. O processo de crioulização no Recôncavo baiano (1750-1800). Afro-Asia, n 33, p. 87132, 2005.

. A formação do candomblé: história e ritual da nação jeje na Bahia. Campinas: Ed. Unicamp, 2006.

PIRES, Maria de Fátima N. O crime na cor: a experiência escrava no alto sertão da Babia: Rio de Contas e Caetité - 1830-1888. São Paulo: Annablume, 2003.

Fios da Vida: trajetórias de escravos e libertos no Alto Sertão da Bahia. Rio de Contas e Caetité (1860-1920).

Tese de doutorado apresentada ao Programa de Pós-graduação em História da USP. São Paulo, 2005.

REIS, Isabel Cristina Ferreira dos. História de vida familiar e afetiva de escravos na Bahia do século XIX. Salvador: CEB, 2001.

REIS, João José. A greve negra de 1857 na Bahia. Revista USP, nº 18, p. 7-29, 1993.

. De olho no canto: trabalho de rua na Bahia na véspera da abolição. Afro-Ásia, no 24, p. 199-242, 2000.

. Rebelião escrava no Brasil. A história do levante dos malês (1835). São Paulo: Companhia das Letras, 2003.

SANTOS, Jocélio Teles dos. De pardos disfarçados a brancos pouco claros: classificações raciais no Brasil dos séculos XVIII-XIX. Afro-Ásia, no 32, p. 115-137, 2004.

SANTOS FILHO, Licurgo. Uma comunidade rural do Brasil antigo: aspectos da vida patriarcal no sertão da Bahia nos séculos XVIII e XIX. São Paulo: Cia. Editora Nacional, 1956.

SCHWARTZ, Stuart B. Segredos internos: engenhos e escravos na sociedade colonial, 1550-1835. São Paulo: Companhia das Letras, 1988.

SILVA, Antonio de Moraes. Dicionário da Lingua Portuguesa. Lisboa: Tipografia Lacerdina, 1813.

SOARES, Mariza de Carvalho. Devotos da Cor: identidade étnica, religiosidade e escravidão no Rio de Janeiro, século XVIII. Rio de Janeiro: Civilização Brasileira, 2000.

SPIX, Johan B. e MARTIUS, Karl von. Viagem pelo Brasil, 1817-1820. Belo Horizonte/São Paulo: Itatiaia/ EDUSP, 1981.

VASCONCELOS, Albertina Lima. Ouro: Conquistas, tensões, poder, mineração e escravidão - Bahia do século XVIII. Dissertação de Mestrado apresentada ao Programa de Pós-graduação em História da Unicamp. Campinas, 1998.

VERSIANI, Flavio Rabelo; MOTTA, Ronaldo Serôa; SUZIGAN, Wilson (Orgs.). Estatísticas históricas do Brasil: séries econômicas, demográficas e sociais de 1550 a 1988. Rio de Janeiro: IBGE, 1990. 
Kátia Lorena Novais Almeida

\title{
RESUMO
}

O artigo aborda o perfil do alforriado em Rio de Contas, Bahia, no decorrer do século XIX. Para isso, examinaremos a origem (África ou Brasil), nação (no caso dos nascidos na África), cor, sexo e idade, quando possivel, e sua influência nos termos das manumissóes. Ademais, cotejaremos a origem e o sexo do alforriado com os tipos de alforria. Antes disso, é importante conhecermos a composição da escravaria, identificando as mesmas variáveis acima nos escravos que habitavam o município de Rio de Contas, de modo a compará-las com as dos cativos que conquistaram a liberdade. Analisamos as variáveis presentes nas cartas de alforria considerando os periodos entre 1800-1850; 1850-1871 e 1871 1888, e comparamos, sempre que possivel, com outras regiōes da Bahia e do Brasil.

Palavras-chave: Alforria, Rio de Contas, século XIX.

\begin{abstract}
This paper addresses the profile of the freed population in Rio de Contas (Bahia, Brazil) over the $19^{\text {th }}$ century by examining their origin (Africa or Brazil), nation (for Africans), color, sex and, whenever possible, age, and how such variables influenced the terms of manumission. The relationship between the kinds of manumission and both origin and sex is further investigated after identifying the same variables above in the enslaved population in the municipality in order to enable a comparison with those who conquered their freedom. Letters of manumission dated 1800-1850, 1850-1871 and 1871-1888 are examined for the variables at stake and, whenever feasible, data from other regions in Babia and Brazil are used for comparison.

Keywords: Manumission, Rio de Contas, 19th century.
\end{abstract}

